\title{
PREDEVELOPMENT HYDROLOGY OF THE SALT RIVER INDIAN RESERVATION, EAST SALT RIVER VALLEY, ARIZONA
}

By B.W. Thomsen and J.J. Porcello

U.S. GEOLOGICAL SURVEY

Water-Resources Investigations Report 91-4132

Prepared in cooperation with the U.S. BUREAU OF INDIAN AFFAIRS 
U.S. DEPARTMENT OF THE INTERIOR

MANUEL LUJAN, JR., Secretary

U.S. GEOLOGICAL SURVEY

Dallas L. Peck, Director

For additional information write to:

District Chief

U.S. Geological Survey 375 South Euclid Avenue Tucson, Arizona 85719
Copies of this report can be purchased from:

U.S. Geological Survey

Books and Open-File Reports Section Federal Center, Box 25425

Denver, Colorado 80225 


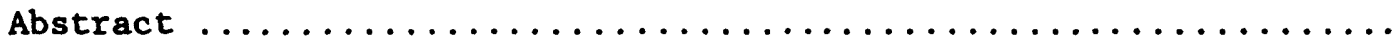

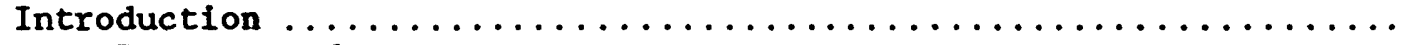

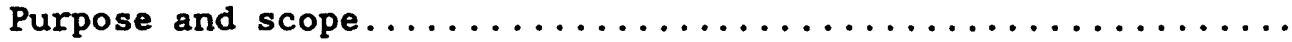

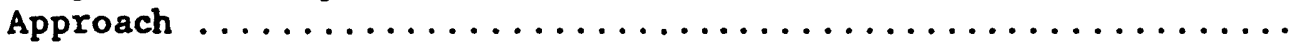

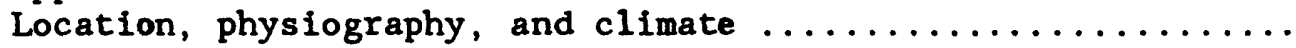

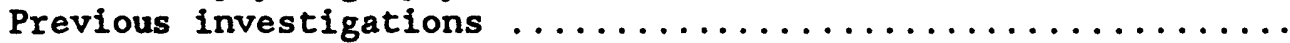

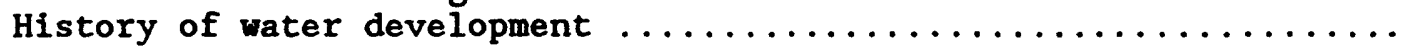

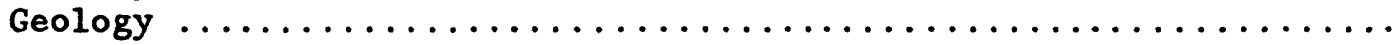

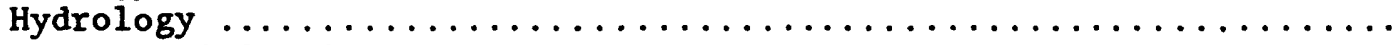

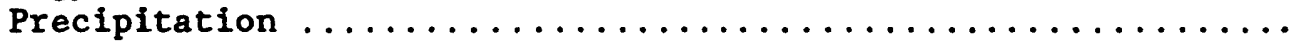

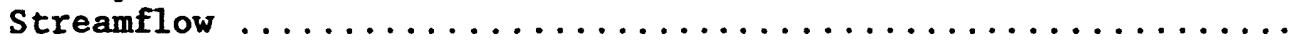

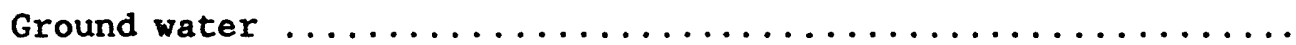

Underflow and mountain-front recharge .............

Hydraulic characteristics of the ground-water

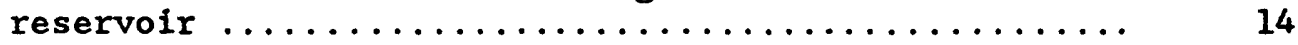

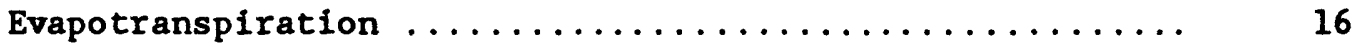

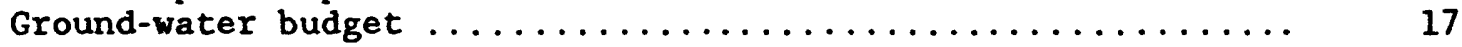

Simulation of ground-water flow $\ldots \ldots \ldots \ldots \ldots \ldots \ldots \ldots \ldots \ldots \ldots$

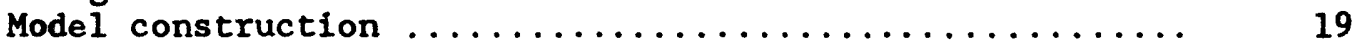

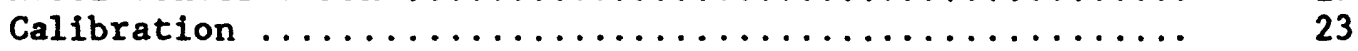

Simulation results ....................... 23

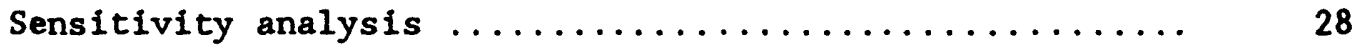

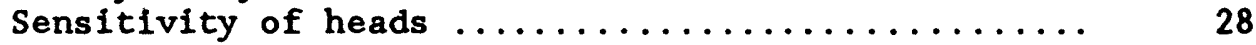

Sensitivity of flow components .............. 30

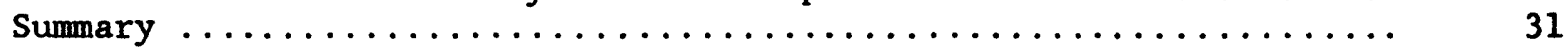

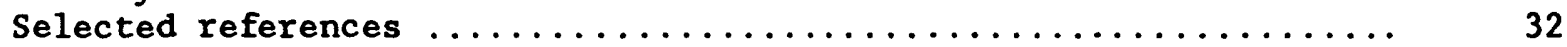

ILLUSTRATIONS

Figure 1-2. Map showing:

1. Location of study area ............... 3

2. Location of streamflow-gaging stations........ 5

3. Graph showing relation between depth to ground

water and annual water use by mesquite........ 
Figures 4. Map showing finite-difference grid and boundary conditions used in the

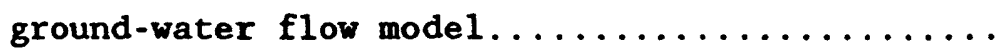

5. Graph showing recent (1973-82) and 1903 profiles of the Salt River bed............

6-7. Maps showing:

6. Simulated transmissivity distribution.......

7. Simulated predevelopment water levels and measured water levels.............

8-11. Graphs showing:

8. Sensitivity of stream-1ine profile to changes in transmissivity values........

9. Sensitivity of stream-1ine profile to changes in riverbed conductance.........

10. Sensitivity of stream-1ine profile to changes in boundary-flux values.........

11. Model sensitivity to changes in transmissivity, riverbed conductance, boundary-flux values, evapotranspiration rate, and evapotranspiration extinction depth......

TABLES

Page

Table 1. Streamflow data at selected streamflow-

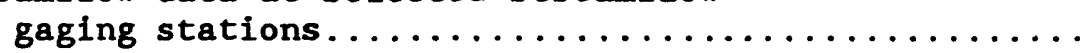

2. Estimated and simulated values of ground-water

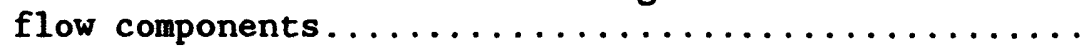

3. Sensitivity of head-residual statistics to model parameters. 
Multiply

inch (In.)

foot ( $f t$ )

mile (mi)

acre

mile per hour $(\mathrm{mi} / \mathrm{h})$

square mile $\left(\mathrm{mi}^{2}\right)$

acre-foot (acre-ft)

acre-foot per acre

(acre-ft/acre)

cubic foot per second $\left(\mathrm{ft}^{3} / \mathrm{s}\right)$

gallon per minute (gal/min)

foot squared per day $\left(f t^{2} / d\right)$

foot per mile ( $\mathrm{ft} / \mathrm{mi}$ )

degree Fahrenheit $\left({ }^{\circ} \mathrm{F}\right)$
By

To obtain

25.40

0.3048

1.609

0.4047

1.609

2.590

0.001233

0.3047

0.02832

0.06309

0.0929

0.1894

(temp $\left.{ }^{\circ} \mathrm{F}-32\right) / 1.8$ millimeter

meter

kilometer

hectare

kilometer per hour

square kilometer

cubic hectometer

cubic meter per square meter

cubic meter per second

liter per second

meter squared per day

meter per kilometer

degree Celsius

Sea level: In this report "sea level" refers to the National Geodetic Vertical Datum of 1929-a geodetic datum derived from a general adjustment of the first-order level nets of the United States and Canada, formerly called "Sea Level Datum of 1929." 


\title{
PREDEVELOPAENT HYDROLOGY OF THE SALT RIVER IKDIAN RESERVATION, EAST SALT RIVER VALLET, ARIZONA
}

By

B.W. Thomsen and J.J. Porcello

\begin{abstract}
Predevelopment hydrologic conditions in the Salt River Valley were investigated to provide information for the adjudication of water rights of users in the Gila River basin. Prior to development by nonIndian settlers, the Salt River was perennial through the Salt River Indian Reservation. The ground-water reservoir was filled to capacity or nearly so and was sustained mainly by infiltration of water from the Salt River. Water levels generally were 10 to 70 feet below the land surface. The direction of ground-water flow was from north to south in Paradise Valley and from east to west along the flood plain of the Salt River and in the area south of the river.

The average annual discharge of the Salt River before development was estimated to be $1,250,000$ acre-feet and the median annual discharge 950,000 acre-feet. These estimates are based on recorded data with adjustments for results of tree-ring studies and estimates of upstream diversions and reservoir evaporation.

A ground-water flow model was developed to simulate groundwater flow, riverbed infiltration, mountain-front recharge, and evapotranspiration for purposes of evaluating predevelopment ground-water conditions. The model represents average conditions in the ground-water system before the system was affected by storage and diversion of streamflow upstream from the reservation. Average values for components of ground-water flow determined from the model for the study area include recharge by infiltration from the Salt River, 19,700 acre-feet per year; mountain-front recharge and subsurface inflow, 10,700 acre-feet per year; discharge to the Salt River near Tempe, 9,800 acre-feet per year; evapotranspiration from ground water, 13,300 acre-feet per year; and subsurface outflow, 7,300 acre-feet per year.
\end{abstract}

\section{INTRODUCTION}

In the 1860's and $1870^{\prime} \mathrm{s}$, non-Indian settlers arrived in Arizona in large numbers and began to divert water from the Salt River near the area that became the Salt River Indian Reservation. The Salt River Indian Reservation was established in 1879 along the Salt River in the eastern part of the Salt River Valley. The development and activities since that time have significantly changed the hydrology of the area. The flow of the Salt River and the recharge to the ground-water system on the reservation have been greatly diminished as a result of upstream storage and diversions. Water levels in wells have declined, and the direction of ground-water flow has changed as a result of pumping for irrigation in 
areas adjacent to the reservation. General adjudication to determine water rights of users in the Gila River watershed is being conducted in the superior courts of Arizona under authority established by Arizona Revised Statutes Title 45, Chapter 1, Article 6. To develop data pertinent to the adjudication process, the U.S. Bureau of Indian Affairs entered into a cooperative agreement with the U.S. Geological Survey to evaluate the hydrologic conditions that existed prior to the development of the area by non-Indian settlers.

\section{Purpose and Scope}

The purpose of this report is to describe the hydrologic conditions that existed in the area of the Salt River Indian Reservation prior to development by non-Indian settlers. Non-Indian settlers were diverting significant quantities of water from the Salt River near the reservation in the 1870's (Davis, 1897). Hydrologic data do not exist for the period prior to 1870; therefore, data collected since 1870 were used to evaluate predevelopment conditions, as described in the section entitled "Approach." The results of the evaluation represent long-term average hydrologic conditions.

\section{Approach}

The evaluation of the hydrologic conditions that existed prior to 1870 required estimating the surface flow of the Salt River upstream from the Salt River Indian Reservation and defining the ground-water system in and adjacent to the reservation. Estimates of average flow of the Salt River were based on recorded data with adjustments to represent predevelopment conditions. The adjustments were based on the recorded effects of development on river flows and mathematical evaluations of climatic trends. Studies of relations between streamflow and tree rings were used to help substantiate estimates of the predevelopment flow of the Salt River.

The ground-water system was evaluated by using a mathematical model. The model covers an area larger than the reservation ( $f \mathrm{~g}_{\mathrm{g}}$. 1 ) in order to encompass parts of the mountain ranges that form physical boundaries to much of the ground-water system. The model parameters were estimated from published values and recorded field data; each parameter was estimated independently. Evapotranspiration was calculated by using the oldest maps and photographs available to determine areas and types of vegetation and applying evapotranspiration rates determined in recent studies.

\section{Location, Physiography, and Climate}

The study area includes about $950 \mathrm{mi}^{2}$ in south-central Arizona, of which about $77 \mathrm{mi}^{2}$ is in the Salt River Indian Reservation (fig. 1). The area is characterized by broad desert plains dissected by many arroyos and separated by rugged relatively low mountains. The altitude of the 


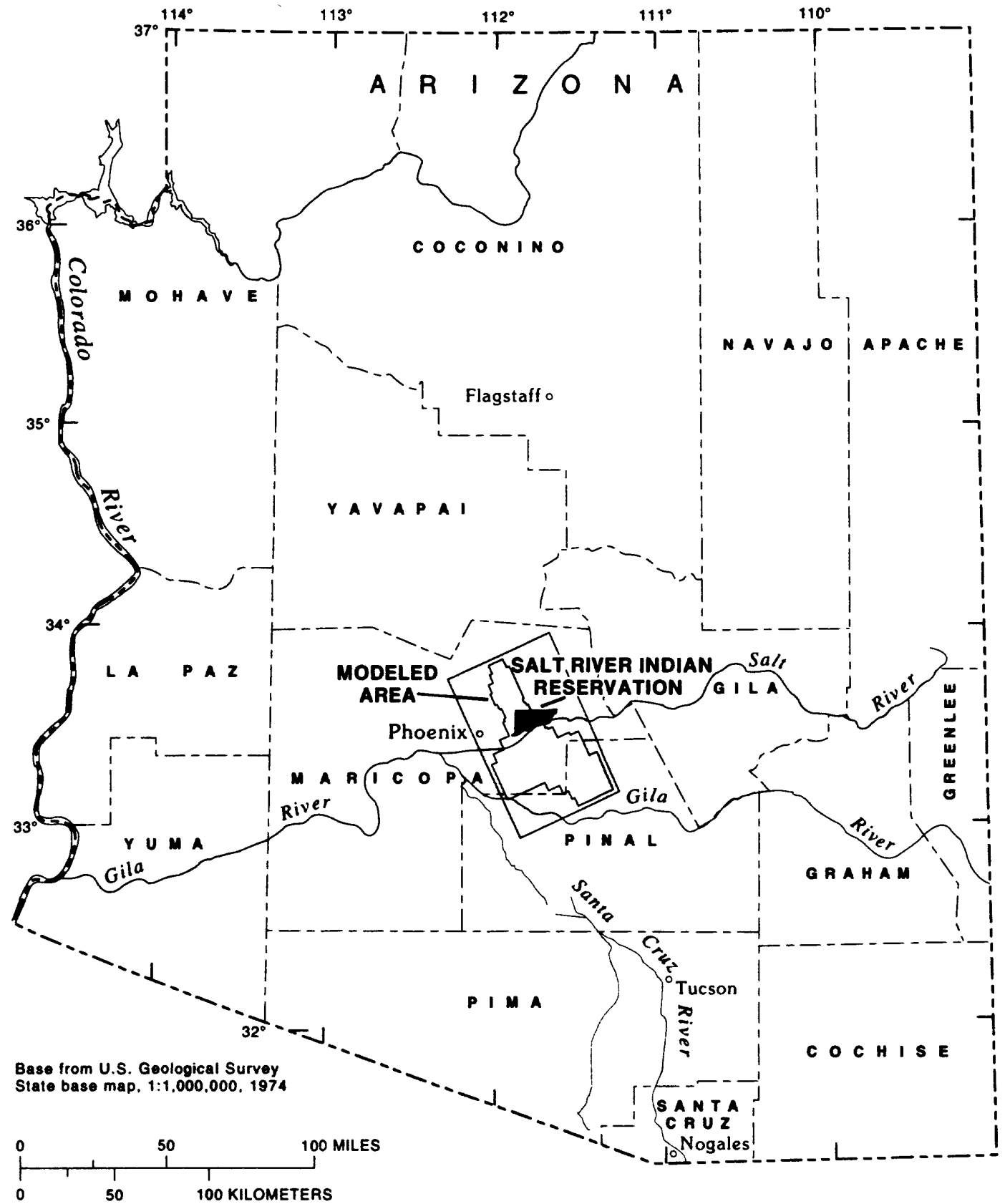

Figure 1.--Location of study area (shaded). 
desert plains ranges from 2,200 ft above sea level north of the reservation to less than $1,200 \mathrm{ft}$ at the southwest corner. The Phoenix and South Mountains, which are on the west side of the study area, reach altitudes of $2,500 \mathrm{ft}$. The McDowe 11 and Superstition Mountains, which are on the east side, are at altitudes of about 4,000 and $5,000 \mathrm{ft}$, respectively. The major streams in the area are the Salt and Gila Rivers and Queen and Cave Creeks. The Salt River drains the northern part of the area, and the Gila River drains the southwestern part. Queen Creek, a tributary to the Gila River, drains the southeastern part, and Cave Creek crosses the northwest corner of the study area (fig. 2). The Salt River and its major tributary, the Verde River, drains more than $12,000 \mathrm{mi}^{2}$ north and northeast of the reservation (fig. 1) and, prior to the activities of the non-Indian settlers, contributed perennial flow through the study area.

The dominant native vegetation types are mesquite and saltbush along the washes and palo verde and cacti on the hills. Creosote bush covers most of the desert floor except where it has been replaced by cultivated farmland. Mesquite, cottonwood, and willow trees grew in places along the river when non-Indian settlers arrived (Lee, 1904) but most have been removed.

The climate is dry and incapable of supporting more than a minimum vegetative growth without irrigation. Summers are hot, and daily temperatures usually exceed $100^{\circ} \mathrm{F}$ from mid-June through August. Mean daily temperatures range from about $64^{\circ} \mathrm{F}$ to $105^{\circ} \mathrm{F}$. The relative humidity generally is low, ranging from about 20 to 50 percent (Sellers and others, 1985).

Winters are mild, and average temperatures range from $30^{\circ} \mathrm{F}$ to $40^{\circ} \mathrm{F}$ in early morning and from $60^{\circ} \mathrm{F}$ to $80^{\circ} \mathrm{F}$ in the afternoons. Subfreezing temperatures occur on only a few days during an average year (Sellers and others, 1985). Mean daily temperatures range from about $33^{\circ} \mathrm{F}$ to $70^{\circ} \mathrm{F}$.

Annual precipitation averages about 8 in. and results mainly from two types of storms. Summer thunderstorms, which develop as a result of the flow of moist-tropical air from the Gulf of Mexico, make July and August the wettest months. Regional storms from the Pacific Ocean produce gentle widespread showers during the fall and winter months.

Wind movement in the area is relatively 1ight. In 1895, the monthly average was about $5 \mathrm{mi} / \mathrm{h}$ at Phoenix (Davis, 1897, p. 31). U.S. Weather Bureau records for January 1948 through December 1955 show that average wind speeds do not exceed $8.3 \mathrm{mi} / \mathrm{h}$ at Phoenix (Sellers and Hill, 1974, p. 30).

\section{Previous Investigations}

An investigation of the water supplies avallable for irrigation in the Salt and Gila Valleys near Phoenix, Arizona, was made in 1896 by Authur P. Davis (1897). This investigation dealt mainly with surface-water supplies. W.T. Lee (1905) investigated the underground waters of the Salt River Valley; his report presents tabulations of well records, water levels, and chemical quality of ground water and includes descriptions of geology, physiography, and the economics of pumping ground water. Ground 


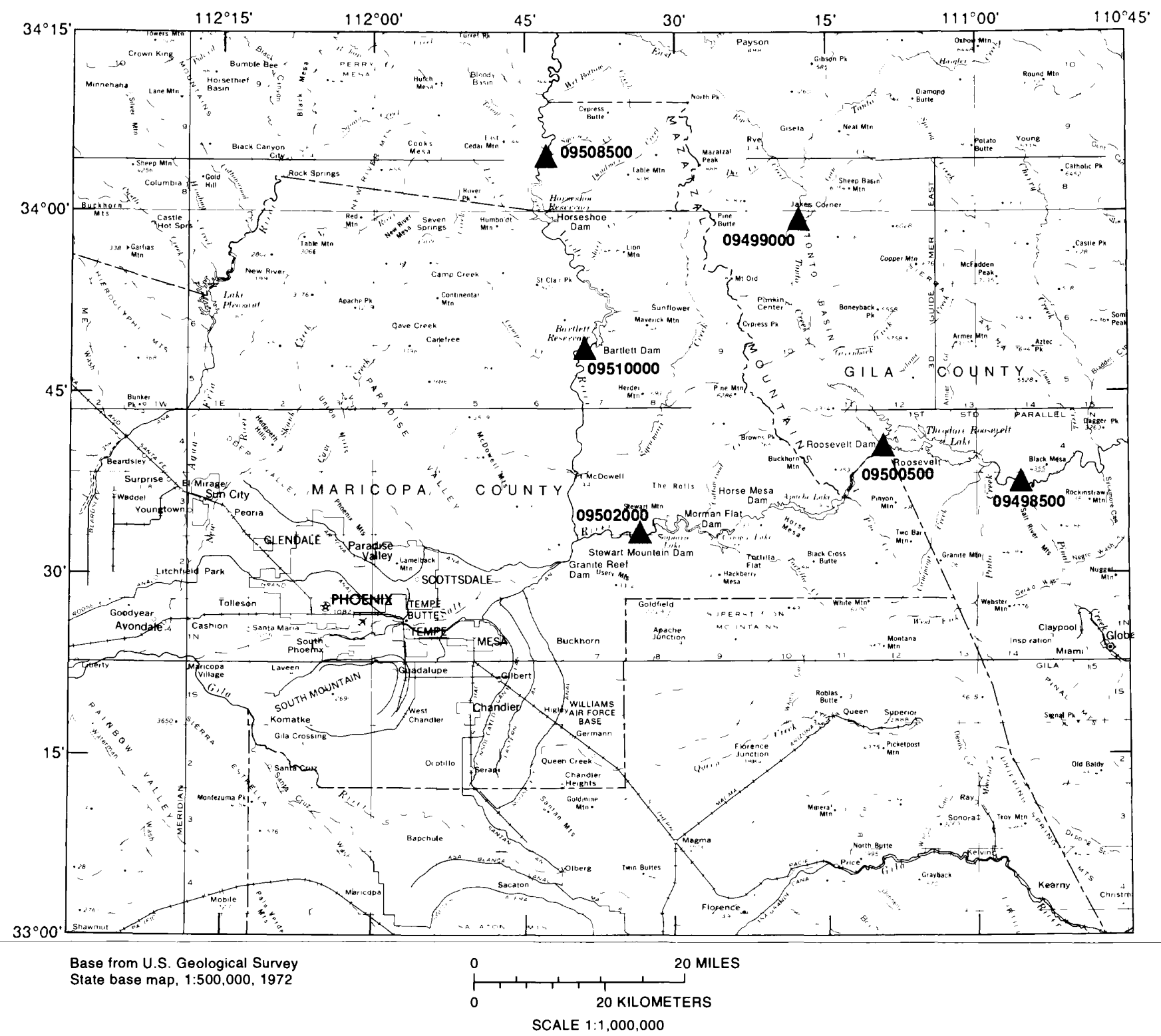

EXPLANATION

09499000 STREAMFLOW-GAGING STATION AND NUMBER

Figure 2.--Location of streamflow-gaging stations. 
water of the Arizona territory was examined to determine its suitability for sanitary, irrigation, and technical uses (Skinner, 1903).

A study of Paradise Valley was made to evaluate the possibility of developing a ground-water supply for Irrigation (Meinzer and E11is, 1915). McDonald and others (1947) collected information on the avaliability of ground water in Paradise Valley as a possible source of municipal supply for the City of Phoenix. Arteaga and others (1968) updated knowledge of ground-water conditions in Paradise Valley. Two reports present records of wells and related ground-water data in the Queen Creek area (Babcock and Halpenny, 1942; Skibitzke and others, 1950).

An electrical-analog model of the ground-water system in central Arizona was used to determine the probable future effects of continued ground-water withdrawal (Anderson, 1968). The model was constructed by using the known hydrologic characteristics of the waterbearing rocks and the pumping history through 1964. Ross (1980) developed a digital model to evaluate the effects of a proposed well field on water levels in wells on the Salt River Indian Reservation.

Maps showing water-level altitudes for 1976 and water-level changes for 1923-76 in the eastern part of the Salt River Valley were prepared by Laney and others (1978). Maps showing ground-water conditions in the Salt River Valley as of 1983 were prepared by Reeter and Remick (1986). Geologic and hydrologic characteristics of the water-bearing units in the eastern part of the Salt River Valley were described by Laney and Hahn (1986). Description of hydrologic conditions and distribution of aquifer materials in alluvial basins (Freethey and others, 1986) are pert1nent to the study area. Ground-water conditions for 1900 and 1986 and changes in ground-water conditions were described by Thomsen and Miller (1991).

\section{HISTORY OF WATER DEVELOPMENT}

Most of the Salt River Valley was occupled and irrigated by the Hohokam Indians from about 300 B.C. to A.D. 1450 (Masse, 1981). Remnants of prehistoric villages and canal systems were noted by archeologists in 1887 , but by 1903 , most of the surface evidence of these villages and canal systems had been obliterated by farming and construction. On the basis of the remains of extensive irrigation works, the amount of land irrigated under the prehistoric system was estimated to have been at least 250,000 acres (Hodge, 1893). Recent archeological studies of the Hohokam irrigation system have recorded more than $300 \mathrm{mi}$ of main canals and $1,000 \mathrm{mi}$ of smaller canals in the Salt River Valley (Masse, 1981).

Modern irrigation in the Salt River Valley was begun by John $W$. Swilling in 1867 (Salt River Project, 1970). The Swilling Ditch, as it was originally called, was on the north side of the river about $5 \mathrm{mi}$ east of Phoenix. In 1868 the canal became known as the Salt River Valley Canal (Davis, 1897). In 1870 the Tempe Canal was constructed on the south side of the river about $7 \mathrm{mi}$ upstream from the Salt River Valley Canal. Other canals constructed on the south side of the river included the San Francisco, Utah, Mesa, and Consolidated Canals built in the $1870^{\prime} \mathrm{s}$ and the 
Highland Canal built in 1889. On the north side of the river, the Grand Canal was built in 1878 and the Arizona Canal in 1883-84 (Davis, 1897).

Reliable figures on the amount of land irrigated in the late 1800 's were difficult to obtain. The farmers did not keep good records, and in many cases the amount of land claimed as irrigated was that "under ditch" (land to which water might be taken). According to the Eleventh Census, the total area irrigated in Maricopa County during 1889 was 35, 212 acres (Davis, 1897). Water was claimed, however, for 151,360 acres in 1889, according to records complled under the orders of Judge Kibbey. The average water use on 60,000 acres irrigated in 1895 was 4.6 acre-ft/acre (Davis, 1897).

The need for a dependable supply of water for irrigation led to the construction of reservoirs to store excess runoff and to regulate the flow of the river. The first structure on the Salt River, Roosevelt Dam, was completed in 1911, followed by Mormon Flat Dam in 1925, Horse Mesa Dam in 1927, and Stewart Mountain Dam in 1930. On the Verde River, Bartlett Dam was completed in 1939 and Horseshoe Dam in 1946. The six reservoirs have a combined storage capacity of more than 2 million acre-ft of water, of which about 85 percent is stored on the Salt River.

Many wells were dug or drilled to provide domestic water supplies, but only small quantities of ground water were withdrawn for irrigation in the late 1800's. The use of ground water for irrigation was hampered by the scarcity and cost of suitable power for pumping (Davis, 1897). The quantities of ground water pumped remained relatively small, less than 100,000 acre-ft/yr in the entire Salt River Valley until the early 1920's. Ground-water withdrawals in the Salt River Valley increased gradually and exceeded 1 million acre-ft in 1942 and 2 million acre-ft in 1952 (U.S. Geological Survey, 1986).

\section{GEOLOGY}

The study area is in the Basin and Range physlographic province (Fenneman, 1931), which is characterized by broad alluvial valleys separated by rugged mountains. The mountains are composed mainly of granitic, volcanic, and metamorphic rocks that yield little water. The valley floors are underlain by a wice variety of sedimentary deposits that constitute the main ground-water reservoirs. Deposits consist of unconsolidated to variably consolidated sediments that are several thousand feet thick in places. The sediments include unconsolidated clay, silt, sand and gravel, caliche, gypsum, mudstone, siltstone, sandstone, conglomerate, and anhydrite. The degree of sorting and cementation and the distribution of the different materials varies areally and with depth. Interbedding and lensing are common, and lateral discontinuities caused by high-angle faults could be present in some older units (Laney and Hahn, 1986).

On the basis of geologic and hydrologic properties, the sediments have been divided into four units-red, lower, middle, and upper (Laney and Hahn, 1986). The following description of the sedinentary units is summarized from Laney and Hahn (1986). The red unit was deposited before the period of block faulting associated with the Basin and Range 
structural disturbance. The red unit consists of well-cemented breccia, conglomerate, sandstone, and siltstone. As a result of faulting, the red unit is exposed locally along the mountain fronts, wainly north of the Salt River along the east and west boundaries of the study area; the thickness of the unit is unknown. The lower, middle, and upper units were deposited during and after the period of block faulting. The lower unit consists of clay, silt, mudstone, and evaporite with interbedded sand, gravel, conglomerate, and basalt. The unit is at least $600 \mathrm{ft}$ thick near the mountains and could be as much as $10,000 \mathrm{ft}$ thick southeast of Chandler and in the center of Paradise Valley. The middle unit consists of silt, siltstone, and silty sand and gravel and ranges in thickness from less than $100 \mathrm{ft}$ near the mountains to about $1,000 \mathrm{ft}$ near Williams Air Force Base; the unit is about $800 \mathrm{ft}$ thick in Paradise Valley. The upper unit consists of gravel, sand, and silt and underlies most of the valley floor; most of the unit is unconsolidated, but locally the deposits are strongly cenented by caliche. The upper unit is more than $300 \mathrm{ft}$ thick south and southwest of Mesa and $200 \mathrm{ft}$ thick in Paradise Valley.

\section{HYDROLOGY}

Hydrologic cycle is a term used to denote the circulation of water from the ocean, through the atmosphere, to the land, and back to the ocean. The movement of water over and through the land enroute back to the ocean is the main concern of this study.

Water that moves over the land surface tends to collect and become streamflow. The quantity and duration of streamflow depends, in general, on the quantity, intensity, and type of precipitation and on the nature of the material over which the water passes. As streamflow moves along natural channels, some water might evaporate and thus be lost from the local system, or a part or all of it might percolate into porous materials and become either soll molsture or ground water.

Water that percolates into the earth from either precipitation or streamflow and reaches the water table, or the zone of saturation, is called ground water. Water that is retained in the unsaturated zone above the water table is called soll moisture. Water in the subsurface might return to the land surface and become streamflow where the water table intersects the land surface. The water might move into the unsaturated zone to become soil moisture or it could be removed from the local system by evapotranspiration or by pumping.

\section{Precipitation}

Precipitation is the initial source of water, but not all the precipitation that reaches the land surface is available for man's use. Water that reaches the land surface as precipitation probably proceeds along any of three general paths. The water might evaporate soon after contact with the land surface, move across the land as surface runoff, or penetrate the earth to become either soll molsture or ground water. Recorded precipitation data indicate that the quantity of precipitation can 
be extremely different from year to year, and studies of past climates show long-term changes in precipitation quantities (Sellers, 1965).

Precipitation in the study area averages about $8 \mathrm{in} / \mathrm{yr}$ and occurs mainly as rain. Snow falls in the upper reaches of the rivers that affect the study area. Total precipitation in the study area averages more than 300,000 acre-ft/yr, of which 30,000 acre-ft/yr falls on the reservation. Most of the rainfall on the flatlands of the study area evaporates or is used by vegetation, and virtually none reaches the groundwater reservoir. Precipitation on the mountains tends to collect in channels and run off and can be sufficient in quantity at times to provide recharge to the ground-water system along the mountain fronts.

For 1931-72, annual precipitation averaged 7.60 in. at Scottsdale and 7.57 in. at Mesa and ranged from 3.04 to 13.84 in. at Scottsdale and $2.83 \mathrm{in}$. to 16.64 in. at Mesa (Se11ers and H111, 1974). Precipitation is less than the potential evapotranspiration in all months, but particularly so in April, May, and June.

Most long-term precipitation records in Arizona began between 1895 and 1915 , at least 25 years after the period of interest for this study. The longest continuous precipitation record in Arizona is for Tucson at and near the University of Arizona. During 109 years, annual precipitation averaged $11.41 \mathrm{in}$. and ranged from 5.07 to 24.17 in.; the median value was 10.94 in. A statistical analysis of the Tucson data indicates no trend in precipitation (Thomsen and Eychaner, 1991).

Fritts and others (1979) used tree-ring data to evaluate climatic variations over a longer time period (1602-1970) and showed that average winter precipitation during 50 -year intervals can vary by 20 percent over much of the United States. The percentage of agreement, however, between reconstructed and observed precipitation was greatest in the southwestern United States, including Arizona.

Each line of evidence suggests that the precipitation regime before 1870 was similar to the current regime; therefore, precipitation estimates using recent data are considered to be representative of predevelopment time. Precipitation records at Phoenix date back to 1877 but records for 7 years between 1886 and 1896 are missing. The average annual precipitation was 7.54 in. at the Phoenix post office for 1877 to 1967 and 7.26 in. at the Phoenix airport for 1938 to 1983 . Annual precipitation ranged from 2.85 to 19.73 in. at the post office and 2.82 to 16.26 in. at the airport, and median values were 6.85 in. at the post office and 7.09 in. at the airport.

\section{Streamf low}

The Salt River was a perennial stream and the main source of water in the study area when the non-Indian settlers arrived (Davis, 1897). The Verde River, which joins the Salt River near the east boundary of the Salt River Indian Reservation, was also a perennial stream. Upstream from the confluence of the two rivers, each river drains an area of more than $6,000 \mathrm{mi}^{2}$. The Gila River, Cave Creek, and Queen Creek are related to the 
hydrology of the study area because of their role in recharging the ground-water system.

Records of discharge of the Salt and Verde Rivers have been kept since 1888. The early estimates of discharge were provided by the Arizona Canal Company and the Hudson Reservoir and Canal Company (Davis, 1897). Subsequently, estimates of dally or monthly discharge were compiled by the U.S. Bureau of Reclamation and the Salt River Valley Water Users' Association (U.S. Geological Survey, 1954). Early estimates of discharge were made on the Verde River near Fort McDowell and on the Salt River at two sites - one called "at McDowell," which was upstream from the confluence with the Verde River, and one called "at Arizona Dam," which was downstream from the confluence with the Verde River. Arizona Dam was about $2.5 \mathrm{mi}$ upstream from the present site of Granite Reef Dam. Water-stage recorders were installed on the Verde River above Camp Creek (equivalent to present site below Bartlett Dam, 09510000) in 1925, on the Salt River below Stewart Mountain Dam (09502000) in 1930, and on the Salt River near Roosevelt (09498500) in 1935 ( $f 1 \mathrm{~g} .2$ ). Before the installation of waterstage recorders, discharge of the Verde River was related to staff gages at several sites near the mouth of the river, and discharge of the Salt River near Roosevelt was related to staff gages $1 \mathrm{mi}$ downstream from the recorder site. Records for the Salt River at Roosevelt, just upstream from the site of Roosevelt Dam, include the discharge of Tonto Creek (fig. 2). Although the discharge of the Verde River was measured or estinated at several sites over the years, the records are considered to be equivalent; hence, continuous records are avallable from 1888 to 1986 (table 1). The longest record of discharge for the Salt River is for the site near Roosevelt, which dates from 1913. Discharge records for the Salt River below Stewart Mountain Dam began with the 1931 water year (table 1).

The two gaging stations nearest the confluence of the Salt and Verde Rivers are on the Salt River below Stewart Mountain Dam and the Verde River below Bartlett Dam. Records for these two stations were combined to determine the flow of the Salt River through the study area, and discharge values have been adjusted for storage in reservoirs. On the basis of available records, the combined average discharge of the Salt and Verde Rivers is $1,223,000$ acre-ft/yr; the median discharge is $889,000 \mathrm{acre}-\mathrm{ft} / \mathrm{yr}$. Records for the Verde River date back to 1888 and those for the $S$ alt River to 1931. For the common period of record, 1931-86, the combined average discharge is $1,151,000$ acre-ft/yr, the median discharge is 873,000 acre-ft/yr, and the annual discharge ranged from 282,000 to $3,832,000$ acre-ft. The recorded values reflect the effect of upstrean diversions and reservoir evaporation on the discharge at the confluence of the Salt and Verde Rivers.

Diversions for irrigation in the upper Verde River area average 31,000 acre-ft/yr (Owen-Joyce and Bell, 1983). Additional small diversions for irrigation in the upper Salt River basin bring the total quantity of water diverted for irrigation upstream from the reservoirs to about 40,000 acre-ft/yr. Evaporation from the reservoirs on the Salt and Verde Rivers is estimated to average $110,000 \mathrm{acre}-\mathrm{ft} / \mathrm{yr}$. Estimates are based on pan-evaporation data collected by the Salt River Project since 1954 at Roosevelt and Bartlett Lakes (Dallas Reigle, Hydrologist, Salt River Project, Phoenix, written commun., 1988). Diversions for powerplant operations, storage in stockponds and recreational lakes, and transbasin 
Table 1.--Streamflow data at selected streamflow-gaging stations

\begin{tabular}{|c|c|c|c|c|c|c|}
\hline \multirow[b]{3}{*}{$\begin{array}{l}\text { Station } \\
\text { number }\end{array}$} & \multirow[b]{3}{*}{$\begin{array}{l}\text { Station } \\
\text { name }\end{array}$} & \multirow{3}{*}{$\begin{array}{c}\text { Drainage } \\
\text { area, } \\
\text { in square } \\
\text { miles }\end{array}$} & \multirow[b]{3}{*}{$\begin{array}{l}\text { Water } \\
\text { years }\end{array}$} & \multicolumn{3}{|c|}{ Annual runoff } \\
\hline & & & & \multicolumn{2}{|c|}{ Mean } & \multirow{2}{*}{$\begin{array}{l}\text { Median } \\
\text { Acre- } \\
\text { feet }\end{array}$} \\
\hline & & & & $\begin{array}{l}\text { Acre - } \\
\text { feet }\end{array}$ & Inches $^{2}$ & \\
\hline 09500500 & $\begin{array}{l}\text { Salt River at } \\
\text { Roosevelt }\end{array}$ & 5,830 & $\begin{array}{c}1888-1907 \\
1910-13\end{array}$ & 756,000 & 2.44 & 491,000 \\
\hline 09498500 & $\begin{array}{l}\text { Salt River near } \\
\text { Roosevelt }\end{array}$ & 4,306 & $1913-86$ & 653,000 & 2.84 & 514,000 \\
\hline 09502000 & $\begin{array}{l}\text { Salt River below } \\
\text { Stewart } \\
\text { Mountain Dam }\end{array}$ & 6,232 & $1931-86$ & 730,000 & 2.20 & 498,000 \\
\hline 09508500 & $\begin{array}{l}\text { Verde River } \\
\text { below Tangle } \\
\text { Creek }\end{array}$ & 5,872 & $1945-86$ & 411,000 & 1.40 & 319,000 \\
\hline 09510000 & $\begin{array}{l}\text { Verde River } \\
\text { below } \\
\text { Bartlett } \\
\text { Dam }^{3}\end{array}$ & 6,188 & $1888-1986$ & 493,000 & 1.49 & 391,000 \\
\hline 09499000 & $\begin{array}{l}\text { Tonto Creek } \\
\text { above Gun } \\
\text { Creek }\end{array}$ & 675 & $1942-86$ & 114,000 & 3.16 & 66,700 \\
\hline
\end{tabular}

'The complete 8-digit station number for each station, such as 09498500 , includes the 2-digit part number "09" plus the 6-digit downstream order number "498500."

2 One inch of runoff is the volume equivalent to a layer of water 1 inch deep over the entire basin.

${ }^{3}$ Data adjusted for changes in storage in major upstream reservoirs.

diversions are considered to have a negligible effect on the average discharge of the basin.

The total reduction in the natural discharge of the salt and Verde River basins as a result of evaporation from reservoirs and diversions for irrigation in the upper reaches cannot be accurately determined but is estimated to average $150,000 \mathrm{acre}-\mathrm{ft} / \mathrm{yr}$. Much of the reduction in discharge was occurring in 1931 when discharge records began on the Salt River below Stewart Mountain Dam. A trend analysis using Kendall's tau-b statistic indicated no trend in the combined discharge data for 1931-86.

Tree-ring data provide evidence of past climatic variations. Long-term-growth records of trees and a shorter tern streamflow record can be used to estimate streamflow for the longer period using statistical 
multiple regression (Fritts, 1976). Tree-ring data were used to extend the annual- and seasonal-discharge records of the Salt and Verde Rivers back to A.D. 1580 (Smith and Stockton, 1981). The extended records were for the gaging stations on the Salt River near Roosevelt and the Verde River below Tangle Creek. The 400 years of reconstructed discharge records were divided into five 80-year periods, and the average discharge for four of the five periods was less than for the period of record for each basin. When the reconstructed discharge records for the two basins were combined, the average discharge for the five 80-year periods ranged from 83 to 99 percent of the average discharge for the period of record. The average discharge for the entire 400 years was 91 percent of the average for the period of record.

The annual discharge of the natural (predevelopment) Salt-Verde drainage basin into the study area is estimated to average $1,250,000$ acre-ft. This estimate is based on the recorded data with adjustment for the results of the tree-ring study and the estimates of upstream diversions and reservoir evaporation. The median annual discharge is estimated to be 950,000 acre-ft.

The Salt River undoubtedly was a constant source of recharge to the ground-water system in the study area before the arrival of non-Indian settlers. Water-level data compiled by Lee (1905) showed that water moved from the Salt River to the aquifer in the first $10 \mathrm{mi}$ downstream from Granite Reef Dam, but about $3 \mathrm{mi}$ farther downstream, water moved from the aquifer back to the Salt River. Flow of the Gila River was also a source of recharge to the ground-water system in the southern part of the study area (Thomsen and Eychaner, 1991).

Queen Creek, which heads in the mountain area south of the Salt River and east of the study area, is tributary to the Gila River. The average discharge of Queen Creek was about 5,000 acre-ft/yr, and most of the water infiltrated into the alluvium near the contact with the mountain area. Flood-control structures have changed the flow pattern of Queen Creek.

Cave Creek drains the mountain area north of Paradise Valley and flows across the northwest corner of the study area where its channel is in coarse alluvium. The channel is dry most of the time but carries water occasionally in response to intense rainfall. Flow is perennial in the upper reaches of Cave Creek, but the water generally infiltrates into the alluvium several miles upstream from the study area. The average discharge of Cave Creek is estimated to be 5,000 to 10,000 acre-ft/yr.

\section{Ground Water}

Ground water occurs mainly under water-table or unconfined conditions in the sedimentary material that underlies much of the Salt River Indian Reservation and the surrounding area. The water table is that surface in an unconfined water body at which the pressure is atmospheric. The water table is defined by the levels at which water stands in wells that penetrate the water body just far enough to hold standing water. When Lee (1905) investigated the underground waters of the Salt River Valley, water levels were from 10 to $70 \mathrm{ft}$ below the land surface in the developed 
area. These water levels could have been higher than the predevelopment level owing to infiltration of diverted irrigation water. Seepage losses were large in the many long ditches required to carry water to scattered tracts of land, and irrigators applied water very lavishly in early spring when water was abundant (Davis, 1897, p. 43). However, water levels reportedly had declined "In the past few years," and the decline was attributed to the drought that prevalled during those years and to the Increasing number of wells in use (Lee, 1905, p. 120-121). The effects of irrigation seepage and drought conditions on the ground-water levels of the early 1900's are unknown but probably are minimal. Thus, the water levels measured by Lee (1905) are considered to adequately represent predevelopment conditions. Lee (1905, p. 119) described the water table as "a comparatively regular plain, sloping in general with the grade of the river." The direction of ground-water movement in 1900 was from east to west along the flood plain of the Salt River and in the area south of the river and from north to south in Paradise Valley. The ground-water reservoir apparently was filled to capacity or nearly so and was sustained mainly by the infiltration of water from the Salt River.

Mountain ranges that border much of the area impede the movement of ground water. The rocks that form the mountains generally are not water bearing but might, where fractured, yield as much as a few tens of gallons per minute of water to wells. On the valley floor, the upper unit has excellent water-bearing characteristics and, where saturated, could yield as much as $4,500 \mathrm{gal} / \mathrm{min}$ of water to wells. During floods on the Salt River and Queen Creek, the upper unit readily accepts large volumes of recharge. In the south-central part of the area where deposits are cemented by caliche, ground water is perched in the upper unit (Laney and Hahn, 1986). The middle unit generally will yield as much as 1,000 gal/min of water to wells; however, north of Mesa, the unit yields about $4,000 \mathrm{gal} / \mathrm{min}$ of water locally to wells. The lower unit yields $50 \mathrm{gal} / \mathrm{min}$ or less of water to wells in many areas; however, the conglomerate and the sand and gravel components of the unit could yield as much as $3,500 \mathrm{gal} / \mathrm{min}$ of water to wells. The red unit yields as much as $1,000 \mathrm{gal} / \mathrm{m} 1 \mathrm{n}$ of water to wells near Scottsdale (Laney and Hahn, 1986).

Recharge to the ground-water system occurs mainly from infiltration of streamflow. Prior to development, the Salt River was the main source of recharge. Queen Creek, Cave Creek, and the Gila River contrib-uted small quantities of recharge on the periphery of the study area. Mcuntain-front runoff from the McDowell and superstition Mountains contributed small quantities of recharge in the Paradise Valley and Queen Creek areas.

Water is discharged from the ground-water system by surface flow and underflow from the area and by evapotranspiration. Discharge of ground water in the Salt River near Tempe occurred regularly prior to development and probably averaged about 25,000 acre-ft/yr (Lee, 1905, p. 151).

Underflow and Mountain-Front Recharge

Underflow through permeable materials that underlie the surface drainages helps to recharge the ground-water system. The Salt River and 
Queen Creek enter the study area from areas underlain by crystalline rocks of low permeability; hence, the underflow from these drainages probably was negligible. The Gila River and Cave Creek are underlain by alluviun and are potential sources of underflow into the study area. Underflow from the Gila River and mountain-front recharge fron the Superstition Mountains are indicated by predevelopment water levels (Thomsen and Baldys, 1985; Thomsen and Miller, 1991). The quantity of underflow was about 6,000 acre-ft/yr on the basis of hydraulic- conductivity data and estimates of the crosssectional area. Underflow through Paradise Valley was principally from Cave Creek and was calculated to be 6,700 acre-ft/yr (McDonald and others, 1947, p. 11). Freethey and Anderson (1986) estimated the predevelopment underflow from Cave Creek and the mountain-front recharge from the McDowell Mountains to be 4,000 acre-ft/yr, and this value was used in the ground-water budget. Total underflow into the area was estimated to be 10,000 acre-ft/yr.

Underflow southwestward from the area is indicated by predevelopment water levels (Thomsen and Baldys, 1985 ; Thomsen and Miller, 1991). The quantity of underflow could have been as much as 7,000 acre-ft/yr on the basis of transmissivity data and estimates of the cross-sectional area. Underflow along the Salt River between Tempe Butte and South Mountain was estimated to be 1,000 acre-ft/yr. Total underflow from the area probably was about 8,000 acre-ft/yr.

\section{Hydraulic Characteristics of the Ground-Water Reservoir}

The hydraulic characteristics of the ground-water reservoir are the physical properties that control the ability of the material to store and transmit water. These properties depend mainly on the size of openings or interstices and their shape, arrangement, and interconnection. The hydraulic characteristics commonly used to describe ground-water reservoirs are storage coefficient and transmissivity, which provide a measure of the quantity of water stored in the reservoir and the rate at which the reservoir will transmit water. The movement of ground water through a section of aquifer can be expressed by the equation:

$$
Q=T I W,
$$

where

$Q=$ flow, in cubic feet per day;

$T$ - transmissivity, in feet squared per day;

$I$ = hydraulic gradient (dimensionless); and

$W=$ width of section, in feet.

Transmissivity is a function of the hydraulic conductivity and saturated thickness of the reservoir and can be expressed by the equation:

$$
T=K M,
$$


$X$ - hydraulic conductivity, in feet per day, and

$M$ - saturated thickness, in feet.

Hydraulic conductivity is the volume of water at the existing kinematic viscosity that will move in unit time under a unit hydraulic gradient through a unit area measured at right angles to the direction of flow (Lohman and others, 1972). Hydraulic conductivity is expressed in units of length per unit time, such as feet per day.

Transmissivity is the rate at which water at the existing kinematic viscosity is transmitted through a unit width of aquifer under a unit hydraulic gradient. Transmissivity is expressed in consistent units of volume $\left(L^{3}\right)$ per unit time (T) per unit width (L), which reduces to $\mathrm{L}^{2} \mathrm{~T}^{-1}$. In the English system, transmissivity is expressed in cubic feet per day per foot, which reduces to feet squared per day.

The storage coefficient is the volume of water an aquifer releases from or takes into storage per unit surface area of the aquifer per unit change in head (Lohman and others, 1972). In an unconfined water body, it is virtually equal to the "specific yield," which is the ratio of the volume of water that saturated material will yield by gravity drainage to the volume of the material drained. The storage coefficient is expressed as volume $\left(L^{3}\right)$ per unit area $\left(L^{2}\right)$ per unit length $(L)$ and is, therefore, dimensionless. Specific storage is the volume of water released from or taken into storage per unit volune of the porous medium per unit change in head (Lohman and others, 1972).

Quantitative data on the hydraulic characteristics of groundwater reservoirs are obtained from field data on water levels, water-level fluctuations, and natural or artificial discharges (Ferris and others, 1962; Benta11, 1963). Aquifer-test data indicate that transmissivity values in the study area range from about 2,500 to $50,000 \mathrm{ft}^{2} / \mathrm{d}$ and values as great as 75,000 $\mathrm{ft}^{2} / \mathrm{d}$ have been estimated for some local areas (Laney and Hahn, 1986). Most of the aquifer tests were made after the upper part of the aquifer, which in many areas is the most transmissive, had been at least partly dewatered; hence, the transmissivity values are less than they would have been when the aquifer was full. The greatest values of transmissivity occur south of the Salt River in the Mesa area (Anderson, 1968; Laney and Hahn, 1986). In general, transmissivity values range from 20 , vo to $40,000 \mathrm{ft}^{2} / \mathrm{d}$ north of the Salt River and decrease northward into Paradise Valley. Stratification in alluvial material causes transmissivity values to be much larger parallel to the bedding plane than perpendicular to the bedding plane.

The average storage coefficients for sedimentary deposits in central Arizona range from 15 to 20 percent (Anderson, 1968). In simulating the effects of a proposed well field on the ground-water system in the Salt River Indian Reservation, Ross (1980) used a storage coefficient of 0.12 .

The hydraulic gradient averaged about 0.001 and ranged from 0.0006 to 0.004 prior to ground-water withdrawals by the non-Indian settlers. At the present time (1986), hydraulic gradients range fron about 0.002 to 0.03 in most of the area. 


\section{Evapotranspiration}

Evapotranspiration is defined as "water withdrawn from a land area by evaporation from water surfaces and molst soll and plant transpiration" (Langbein and Iseri, 1960). Evaporation is commonly measured by noting the change in water level in an open pan during a given time perlod. Such measurements do not accurately reflect evaporation from natural water bodies because of difference in water temperature, vapor pressure, and water-surface roughness. The rate of evaporation from a small pan usually far exceeds that from a large reservoir or lake. The ratio of lake to pan evaporation is referred to as the pan coefficient. Annual evaporation from a U.S. Weather Bureau Class A pan at Mesa during 1963-73 averaged 106.31 in. (Sellers and H111, 1974). The pan coefficient is about 0.67 , and the average annual lake evaporation is about 70 to 75 in. (U.S. Department of Commerce, 1968). Annual lake evaporation, in feet, multiplied by an area of water surface, in acres, would give the volume of water evaporated, in acre-feet per year. Plants obtain water from precipitation and soil molsture, and deep-rooted plants called phreatophytes obtain much of their water from the capillary fringe and the saturated zone. The rate of transpiration by phreatophytes depends on the availability of water and on the species, cover density and size, and stage of maturity of the plants. The quantity of water withdrawn from the ground-water reservoir by phreatophytes depends on the depth to ground water. The use of water by phreatophytes is greatest when ground water is shallow and decreases as depth to water increases (fig. 3). The relation between water use and depth to water is not well defined for all phreatophyte species but is fairly well defined for mesquite (Anderson, 1976).

The most common species of phreatophytes indigenous to southern Arizona are cottonwood, willow, baccharis (seepwillow), and mesquite (Gatewood and others, 1950). These species probably were the main woodland types of vegetation along the Salt River near the Salt River Indian Reservation prior to the arrival of non-Indian settlers. The area of potential phreatophytic growth was 18,500 acres as determined from topographic maps published in the early 1900's and aerial photographs taken in 1936. Probably only about half the area contained phreatophytes. According to early photographs and descriptions (Davis, 1897; Lee, 1905; Salt River Project, 1970), most of the flood plain and low terraces along the Salt River were covered with grass and were scattered with phreatophytes that were light in density.

An investigation of the consumptive use of water by phreatophytes was made in 1963-71 to determine evapotranspiration before and after clearing phreatophytes on $15 \mathrm{mi}$ of the Gila River flood plain (Culler and others, 1982). Results of the study showed that the annual evapotranspiration averaged $3.7 \mathrm{ft}$ and ranged fron $4.7 \mathrm{ft}$ for dense stands of phreatophytes to $2.1 \mathrm{ft}$ for areas of no phreatophytes. Vegetation consisted mainly of saltcedar and mesquite with scattered cottonwood, seepwillow, seepweed, and arrowweed. Depth to ground water on the flood plain ranged from $5 \mathrm{ft}$ near the river to $20 \mathrm{ft}$ near the outer boundaries of the flood plain. Removal of the phreatophytes resulted in a reduction in evapotranspiration that averaged $1.6 \mathrm{ft} / \mathrm{yr}$ and ranged from 1.2 to $2.2 \mathrm{ft} / \mathrm{yr}$ owing to the differences in the density of phreatophytes. Evapotranspiration after the removal of phreatophytes consisted of 


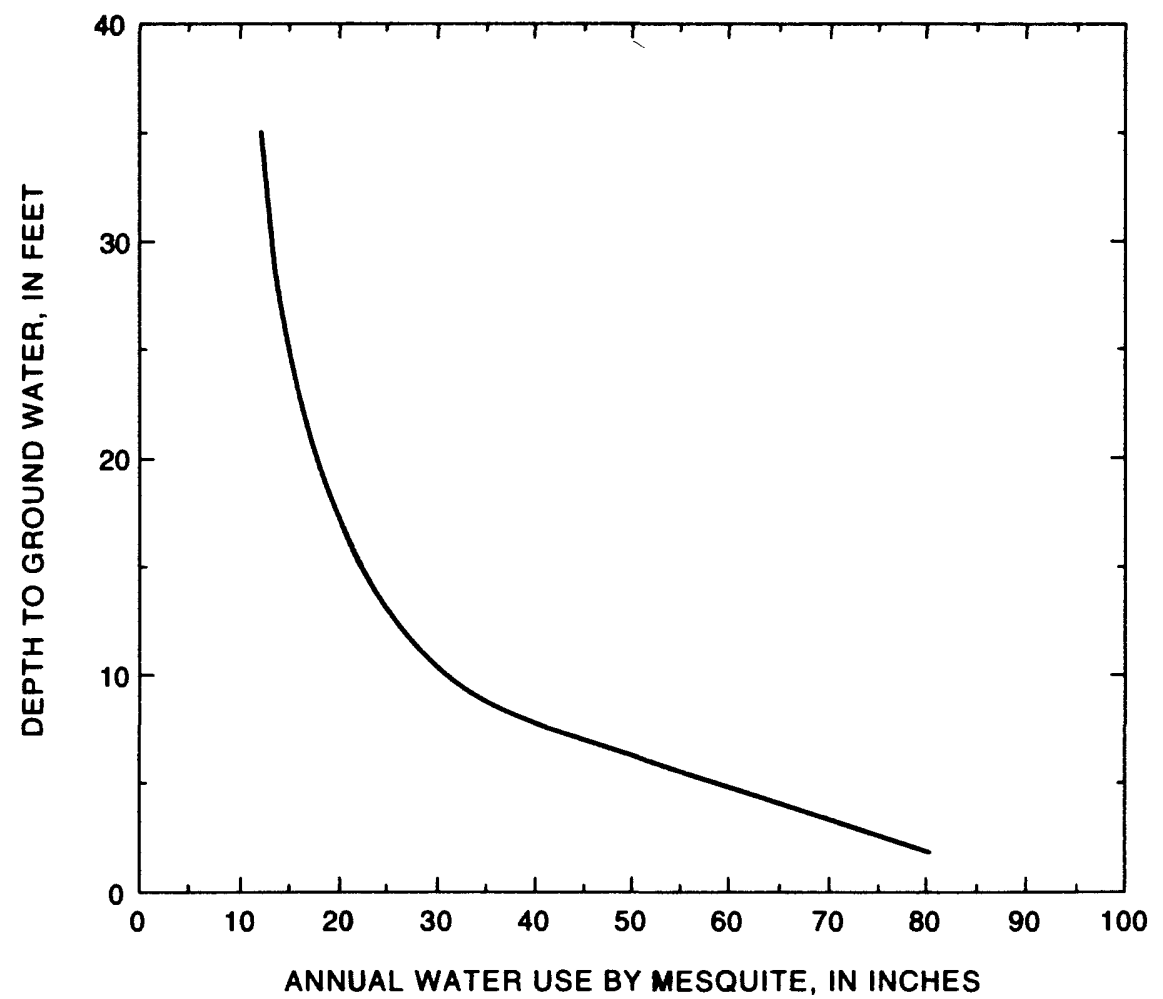

Figure 3.-Relation between depth to ground water and annual water use by mesquite (From Anderson, 1976, fig. 10, p. 46).

evaporation from bare ground and transpiration from annual vegetation. Because phreatophytes obtain their water supply primarily from ground water, the reduction in evapotranspiration that resulted from removal of the phreatophytes is considered to represent a measure of ground water withdrawal by phreatophytes. Precipitation and soil moisture provide a significant part of the evapotranspiration during the period of high potential evapotranspiration (Culler and others, 1982).

Ground-water withdrawal by phreatophytes was estimated to average 15,000 acre-ft/yr on the basis of an evapotranspiration rate of $1.6 \mathrm{ft} / \mathrm{yr}$ and the assumption that phreatophytic growth covered half the potential growth area. Because phreatophytes were scattered and their distribution unknown, the evapotranspiration rate was halved and applied to the entire area of potential phreatophytic growth for modeling purposes.

\section{Ground-Water Budget}

A water budget that accounts for all inflows and outflows was prepared for the ground-water reservoir underlying the study area. Because aquifers were in equilibrium prior to development by non-Indian settlers, the average long-term change in ground-water storage prior to 1870 was considered to be zero. Hence, the sum of all inflows must have equaled the sum of all outflows. 
The average annual water budget for the ground-water reservolr under predevelopment conditions is expressed by the equation:

$$
G_{i}+Q_{r}=G_{0}+Q_{d}+E T_{g}
$$

where

$$
\begin{aligned}
& G_{i} \text { - subsurface inflow, } \\
& Q_{r} \text { - recharge to the aquifer from the Salt River, } \\
& G_{0} \text { - subsurface outflow, } \\
& Q_{d} \text { - discharge to the Salt River from the aquifer, and } \\
& E T_{g} \text { - evapotranspiration from the ground-water reservoir. }
\end{aligned}
$$

All components were evaluated independently except $Q_{r}$, which was computed as a residual. Average values were as follows:

$$
\begin{aligned}
& G_{i}=10,000 \text { acre }-\mathrm{ft} / \mathrm{yr}, \\
& Q_{r}=38,000 \text { acre }-\mathrm{ft} / \mathrm{yr}, \\
& G_{0}=8,000 \text { acre }-\mathrm{ft} / \mathrm{yr}, \\
& Q_{d}=25,000 \text { acre }-\mathrm{ft} / \mathrm{yr} \text {, and } \\
& E T_{g}=15,000 \text { acre }-\mathrm{ft} / \mathrm{yr} .
\end{aligned}
$$

The net flux from the Salt River to the aquifer, $Q_{n}$, is expressed by the equation:

$$
Q_{n}=Q_{r}-Q_{d}
$$

Using the above values, $Q_{n}$ is 13,000 acre-ft/yr.

\section{SIMULATION OF GROUND-WATER FLOW}

The modular three-dimensional, finite-difference ground-water flow model of the U.S. Geological Survey (McDonald and Harbaugh, 1991) was used in the simulation of the predevelopment ground-water flow regime. A two-dimensional application of the model was used because regional flow in the upper and middle lithologic units was predominantly horizontal. The aquifer was simulated as a steady-state flow system because all avallable data suggest that annual ground-water inflows and outflows were about equal (Anderson, 1968; Thomsen and Baldys, 1985). The model was calibrated 
mainly to the earliest avallable well data and was constructed to reflect steady-state ground-water flow conditions that existed before settlement of the East Salt River Valley.

The model solves the following partial-differential equation for three-dimensional flow in a saturated medium (McDonald and Harbaugh, 1988):

$$
\frac{\partial}{\partial x}\left(K_{x x} \frac{\partial h}{\partial x}\right)+\frac{\partial}{\partial y}\left(K_{y y} \frac{\partial h}{\partial y}\right)+\frac{\partial}{\partial z}\left(K_{z z} \frac{\partial h}{\partial z}\right)-W=s_{s} \frac{\partial h}{\partial t},
$$

where

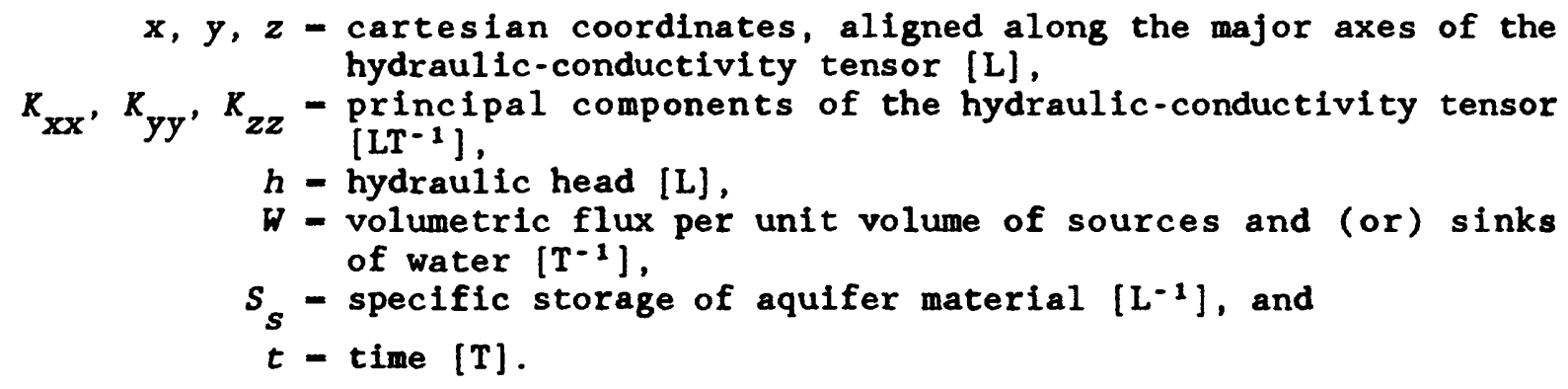

A two-dimensional model simulates no vertical flows except for those embodied in the term, $W$; therefore, head is invariant with respect to altitude, and the vertical-flow term drops out of the equation. Because a steady-state condition implies that inflows and outflows to the aquifer are equal, heads throughout the aquifer also are steady over time. The two-dimensional steady-state flow equation, therefore, is expressed as

$$
\frac{\partial}{\partial x}\left(K_{x x} \frac{\partial h}{\partial x}\right)+\frac{\partial}{\partial y}\left(K_{y y} \frac{\partial h}{\partial y}\right)-W=0 .
$$

The required input data for a two-dimensional steady-state model are the grid and cell dimensions, boundary conditions, and parameter values relating to the hydraulic conductivity, and various components of the term W. For this study, the term $W$ includes the processes of evapotranspiration, riverbed infiltration, and mountain-front recharge. For unconfined aquifers, such as is present in East Salt River Valley, the model allows the user to specify either transmissivity values or hydraulic conductivities and layer thicknesses.

\section{Model Construction}

The finite-difference technique used by the ground-water flow model requires the subdivision of the active ground-water flow region into a grid of rectangular cells, which can be identically sized or variably 
sized. The aquifer was modeled with a grid dimension of 44 rows by 39 columns ( $f i g .4$ ). The cells were variable in size. The grid was designed to place the smallest cells along the channel of the Salt River and the largest cells along the model boundaries. The grid was oriented $24^{\circ} 7^{\circ}$ west of true north so that the cells would be in close alignment with the path of the Salt River because the ground-water budget indicated that the river was the dominant source and sink for subsurface waters under predevelopment conditions. The solution of the steady-state heads at each cell was obtained using the strongly implicit solution procedure of the model with a head-closure criterion of $0.01 \mathrm{ft}$.

Model boundaries were based on previously mapped boundaries between alluvial deposits and crystalline rocks except in the Gila River area where an artificial boundary was established for modeling convenience. The simulation used specified-flux, specified-head, and head-dependent boundaries. Areas of mountain-front recharge were simulated as specifiedflux boundaries. Subsurface outflow at Tempe Butte and the Gila River was simulated with specified-head boundaries. The head altitudes were selected from measurements at nearby wells and from the predevelopment water-level contours. The Salt River was treated as a head-dependent flux boundary; values of head and vertical flux at each river node were computed as a function of the specified stage of the river and the head in the aquifer.

An underflow of 3,300 acre-ft/yr from Cave Creek was distributed evenly over all specified-flux nodes in the northernmost row of the mode 1 , and 700 acre-ft/yr of mountain-front recharge from the McDowell Mountains was distributed evenly along the mountain range. An underflow of 500 acre-ft/yr from the Gila River was applied to two nodes in the southernmost row of the model, and mountain-front recharge of 5,200 acre-ft/yr from the Superstition Mountains was distributed along the mountain range.

Perennial streamflow from the Salt River watershed was simulated as flow in the present (1986) channel of the river. A total of 28 cells were specified as river reaches. The river stages in the upper 10 reaches were set to altitudes that were $2 \mathrm{ft}$ above the average channe1floor altitudes in each cell. River stages in the lower 18 reaches were set equal to water-table altitudes suggested by regional-predevelopment contours (Thomsen and Baldys, 1985). Riverbed altitudes were determined from recent (1973-82) topographic maps and differ by as much as $15 \mathrm{ft}$ in places from altitudes determined from topographic maps pubi ishec in the early 1900's (fig. 5). The differences might result in part from mapping variations but probably result mainly from channel changes.

Although the flood plain of the Salt River was more than one model-cell wide in much of the valley, only a single cell within appropriate grid columns was selected because mean annual widths of channel flow probably were no greater than a few hundred feet (Hodge, 1877). Riverbed conductance was estimated initially from channel geometry and a vertical-hydraulic conductivity of $5 \mathrm{ft} / \mathrm{d}$ was assumed. Riverbed conductance is the product of vertical hydraulic conductivity and area of riverbed sediments in a model cell, divided by the thickness of the riverbed sediments. For simulation purposes, the riverbed thickness for each reach was set arbitrarily at $100 \mathrm{ft}$ except at the edges of the valley where simulated thicknesses ranged from 50 to $90 \mathrm{ft}$. 


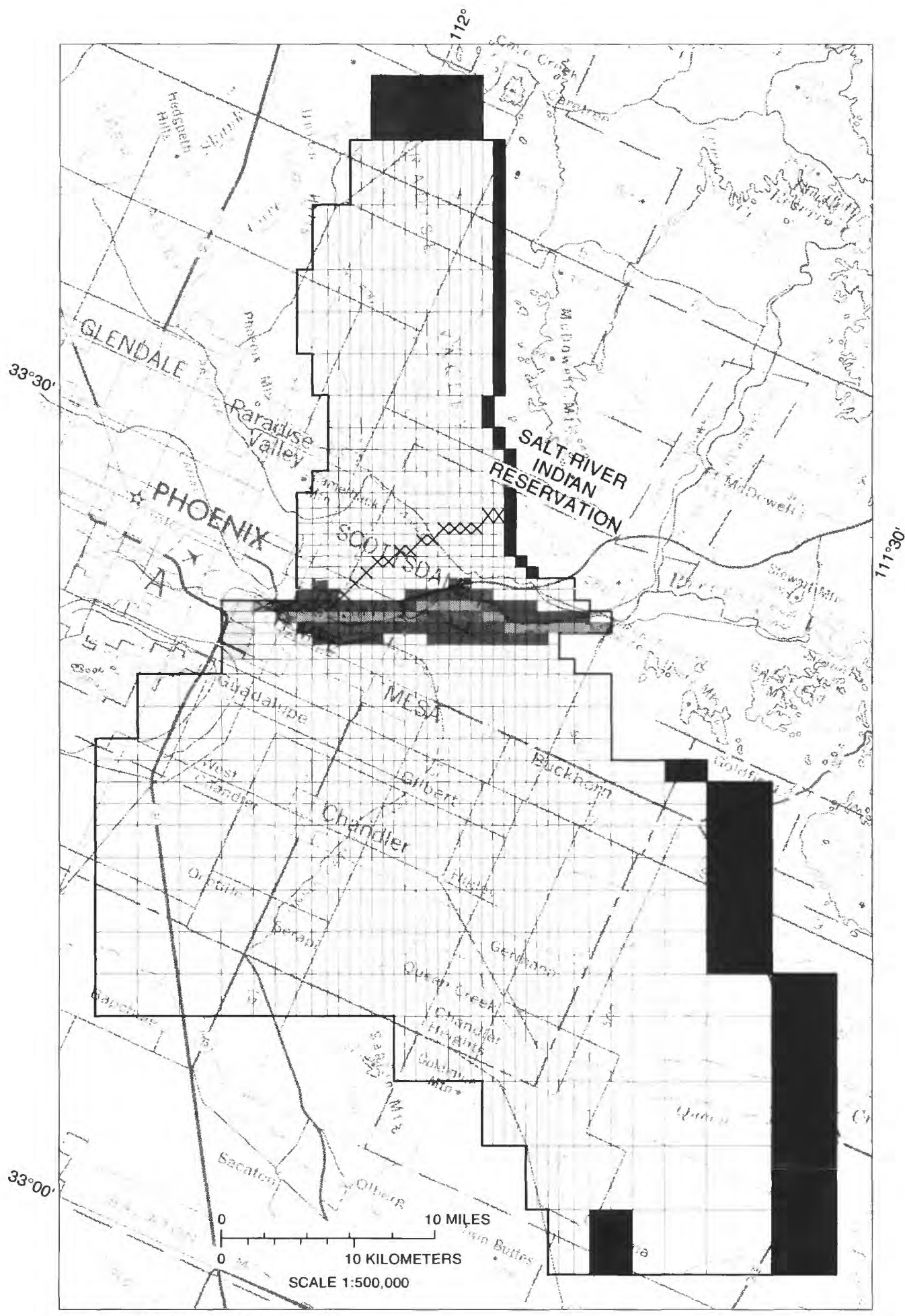

21

Base from U.S. Geological Survey State base map, 1:500,000,1972

EXPLANATION

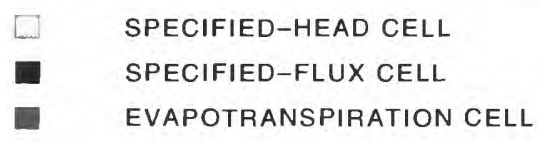

RIVER AND EVAPOTRANSPIRATION CELL

$X \quad$ STREAM-LINE CELL IN CALIBRATED MODELStudied in the sensitivity analysis BOUNDARY OF MODEL

Figure 4.-Finite-difference grid and boundary conditions used in ground-water flow model. 


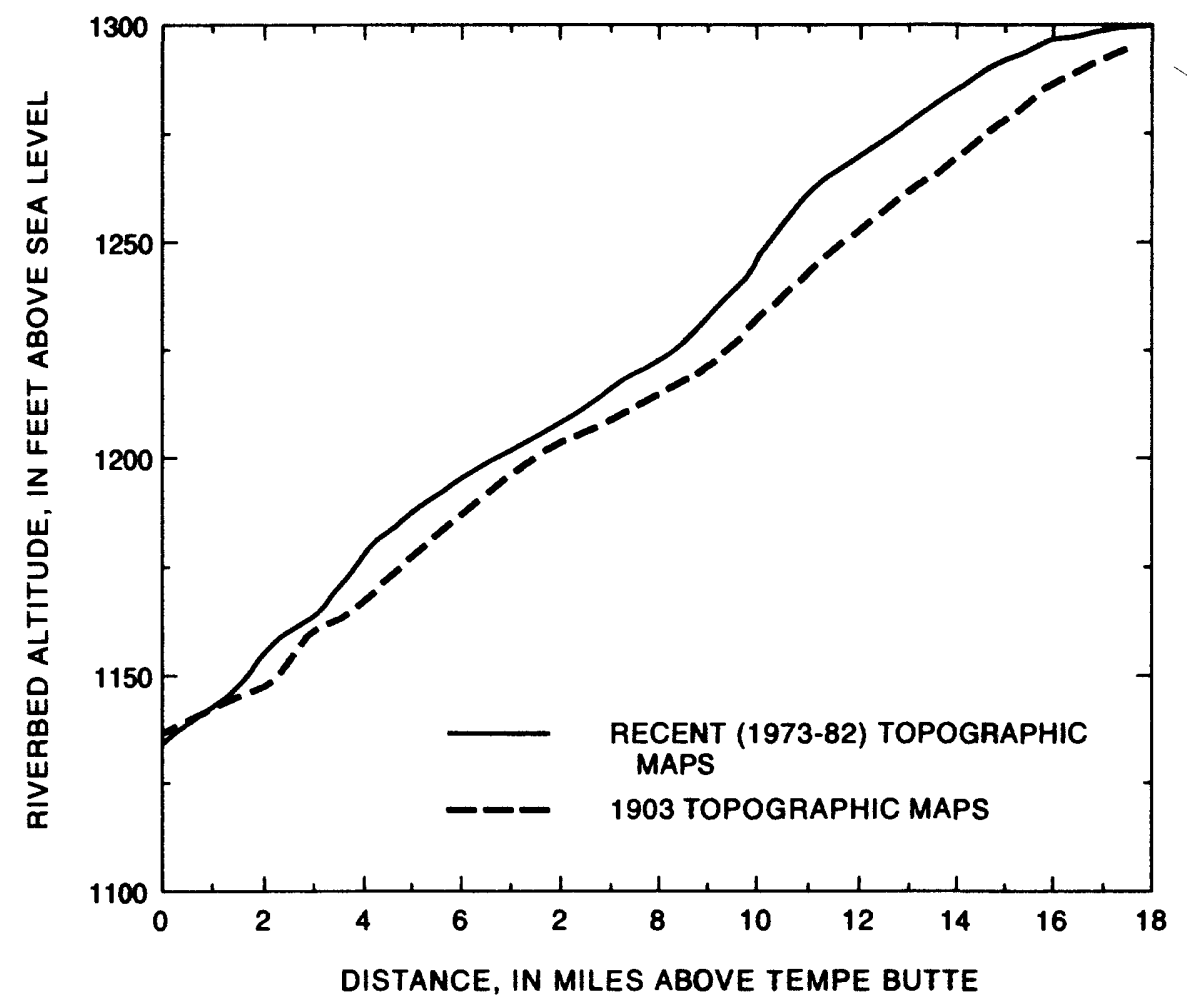

Figure 5.-Recent (1973-82) and 1903 profiles of the Salt River bed.

Evapotranspiration cells were restricted mainly to the flood plain of the Salt River (fig. 4). River cells also were simulated as evapotranspiration cells because of the growth of phreatophytes in the river channel. The evapotranspiration surface, defined as the aquifer-head altitude above which maximum evapotranspiration occurs, was set equal to the altitude of the land surface at most evapotranspiration cells. Within river cells, this surface was set $5 \mathrm{ft}$ above the channel-floor altitude to account for the perennial nature of the river, as well as the topographic relief between the channel floor and banks. The simulated evapotranspiration extinction depth, defined as the depth below which phreatophytes are unable to withdraw ground water, was $30 \mathrm{ft}$.

Simulated transmissivities were selected to reflect the dominant role of the upper unit in the two-dimensional predevelopment ground-water flow system. Estimates of transmissivity for the upper unit were derived from Anderson (1968) and from Laney and Hahn (1986), and the unit was simulated as an isotropic medium. Initial approximations of transmissivity in Paradise Valley were derived mainly from upper-unit contour maps of thickness and percent sand and gravel (Laney and Hahn, 1986). Transmissivities that ranged from 2,000 to $75,000 \mathrm{ft}^{2} / \mathrm{d}$ and transmissivity-distribution patterns suggested by Anderson (1968) and Laney and Hahn (1986) were used as a guide for changes in transmissivity during the calibration process. 


\section{Calibration}

The principal goal of the calibration process was to match simulated-head contours with heads measured at 121 wells while maintaining the various ground-water flow components within reasonable limits of their independent estimates. The calibration was followed by a sensitivity analysis in which variations in model parameters were examined for their relative effects on head configuration and magnitudes of the flow components. The sensitivity analysis was vital in assessing the credibility of the calibrated model because the two-dimensional nature of the model prevented evaluation of how well it would reproduce historical patterns of pumping over the past 50 years.

Many ground-water models are calibrated in a manner that lends more credence to independent estimates of the transmissivity distribution and the ground-water flow budget than to the estimated-head distribution. In this study, the well data provided more information about the flow system than did the transmissivity and budget estimates because only depths to water were directly measured before much of the upper unit was dewatered. Because the transmissivity distribution and the flow components were estimates, rather than measured values, they were considered less reliable than the measured water levels.

Initial estimates of riverbed conductance were based on channel geometries and an assumed vertical hydraulic conductivity of $5 \mathrm{ft} / \mathrm{d}$. These estimates, however, produced an unrealistic distribution of gaining and losing reaches of the Salt River. A reduction of all riverbed conductances by two orders of magnitude produced more reasonable distributions of fluxes with little change in the total volume of flow exchanged between the river and the aquifer. This change reflected adjustments of the estimates of channel geometry and vertical hydraulic conductivity that were used in the original computations of riverbed conductance. Riverbed conductance was reduced because vertical fluxes in the river are proportional to the difference between river and aquifer heads, and that difference was much smaller under predevelopment conditions than under present (1986) conditions.

\section{Simulation Results}

Simulated transmissivities within the Salt River Indian Reservation ranged from $2,000 \mathrm{ft}^{2} / \mathrm{d}$ along the margins of the aquifer to $40,000 \mathrm{ft}^{2} / \mathrm{d}$ near the river (fig. 6). The same range of transmissivities was simulated throughout the study area. Simulated transmissivities were intermediate in magnitude between those given by Anderson (1968) and Laney and Hahn (1986) and exhibited similar spatial trends. The simulation displayed a high-transmissivity zone from central Paradise Valley southwestward toward the Gila River and a low-permeability zone near the town of Queen Creek. Simulated values of evapotranspiration along the Salt River flood plain were in close agreement with initial estimates of evapotranspiration.

Simulated water-level contours generally compared well with the independent estimates of Thomsen and Baldys (1985) and contours derived 
24

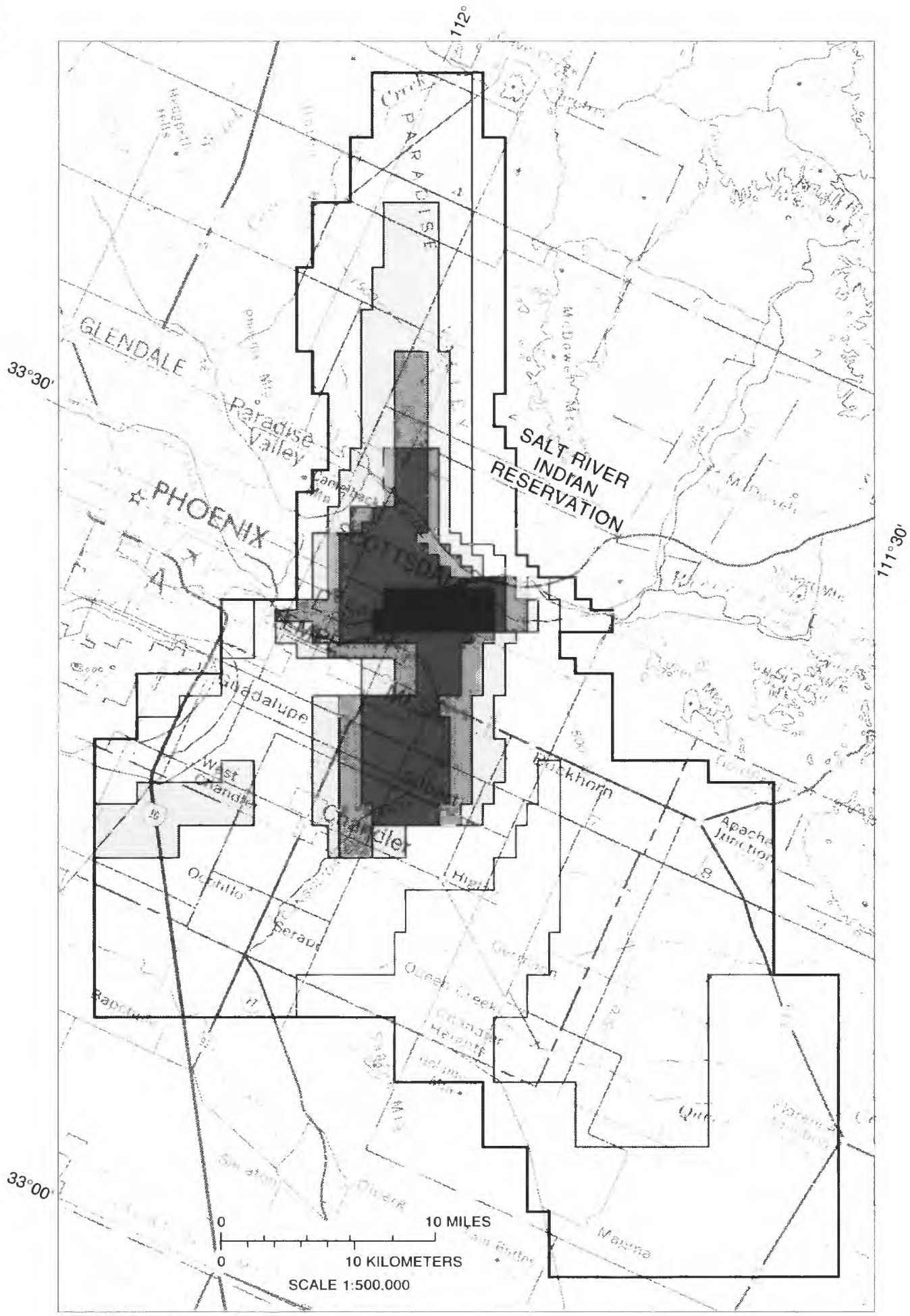

Base from U.S. Geological Survey State base map, 1:500,000, 1972

EXPLANATION

TRANSMISSIVITY, IN FEET SQUARED PER DAY

$\begin{array}{ll}\square 2,000 & \square 20,000 \\ \square 20,000 & 30,000 \\ 25,000 & 40.000\end{array}$

Figure 6.-Simulated transmissivity distribution. 
from water-level measurements shown by Meinzer and Ellis (1915). Contours indicate that the Salt River was a predominantly losing strean in the east half of the study area and a predominantly gaining stream in the west half of the area ( $\mathrm{fig} .7$ ). This result agrees with maps and descriptions given by Lee (1905). Heads computed at river cells generally were a few tenths of a foot within the specified river stages. Similar heads and stages of the river cells and the shapes of the contours crossing the river indicate that the river was the dominant hydrologic feature of the valley.

The shapes of the 1,220-foot and 1,240-foot contours south of the Salt River indicated that some of the predevelopment riverbed recharge flowed southwestward toward the Gila River and the rest followed the general path of the river. The ground-water divide was poorly defined. Mountain-front recharge from the Superstition Mountains and underflow from the Gila River in the southeast corner of the study area flowed westward and then southwestward toward the Gila River in the southwest corner of the study area.

Simulated water-level contours within the Salt River Indian Reservation ranged from 1,160 ft to 1,260 ft along the Salt River (fig. 7). The simulated flow north of the reservation and along its west boundary was derived from underflow from Cave Creek and mountain-front recharge. The shapes of the contours reflect the assumption that mountain-front recharge from the McDowe11 Mountains was a minor source of ground water to the reservation.

Differences between simulated and measured water levels (herein called residuals) were generally less than $\pm 20 \mathrm{ft}$. Residuals ranged from 0 to $96 \mathrm{ft}$, but only 4 of the 121 values were greater than $\pm 30 \mathrm{ft}$. The average-absolute value of the residuals was $10 \mathrm{ft}$, and the standard deviation was $15 \mathrm{ft}$. The root-mean-square average of the residuals also was $15 \mathrm{ft}$. The residual population appeared normally distributed as a group, but slight spatial trends were evident. A zone of negative residuals imediately downgradient from a zone of positive residuals in the Tempe-Mesa area indicates that the water table in this area in 1903 could have been flatter than the predevelopment water table because of the combined effects of drought and recharge from irrigation. A zone of negative residuals immediately north of the Arizona Canal suggests that McDonald and others (1947) were correct in their assumption that the water levels measured by Meinzer and Ellis (1915) in this area were influenced by leakage from the canal. The distribution of head residuals suggests that any temporal trends inherent in the water-level data used were minimal in comparison to the spatial trends.

The simulated predevelopment ground-water inflow to the Salt River Indian Reservation was 26,700 acre-ft/yr; 19,700 acre-ft/yr occurred as infiltration of Salt River flows, and 7,000 acre-ft/yr occurred as underflow from Cave Creek and mountain-front recharge (table 2). About 51 percent of ground-water discharge from the reservation occurred as subsurface outflow along the south and west boundaries of the reservation, and evapotranspiration and discharge to the bed of the Salt River constituted 30 and 19 percent of the discharge, respectively. The net flux of 14,700 acre-ft/yr from the river to the aquifer was slightly greater than the subsurface outflow from the reservation. 
26

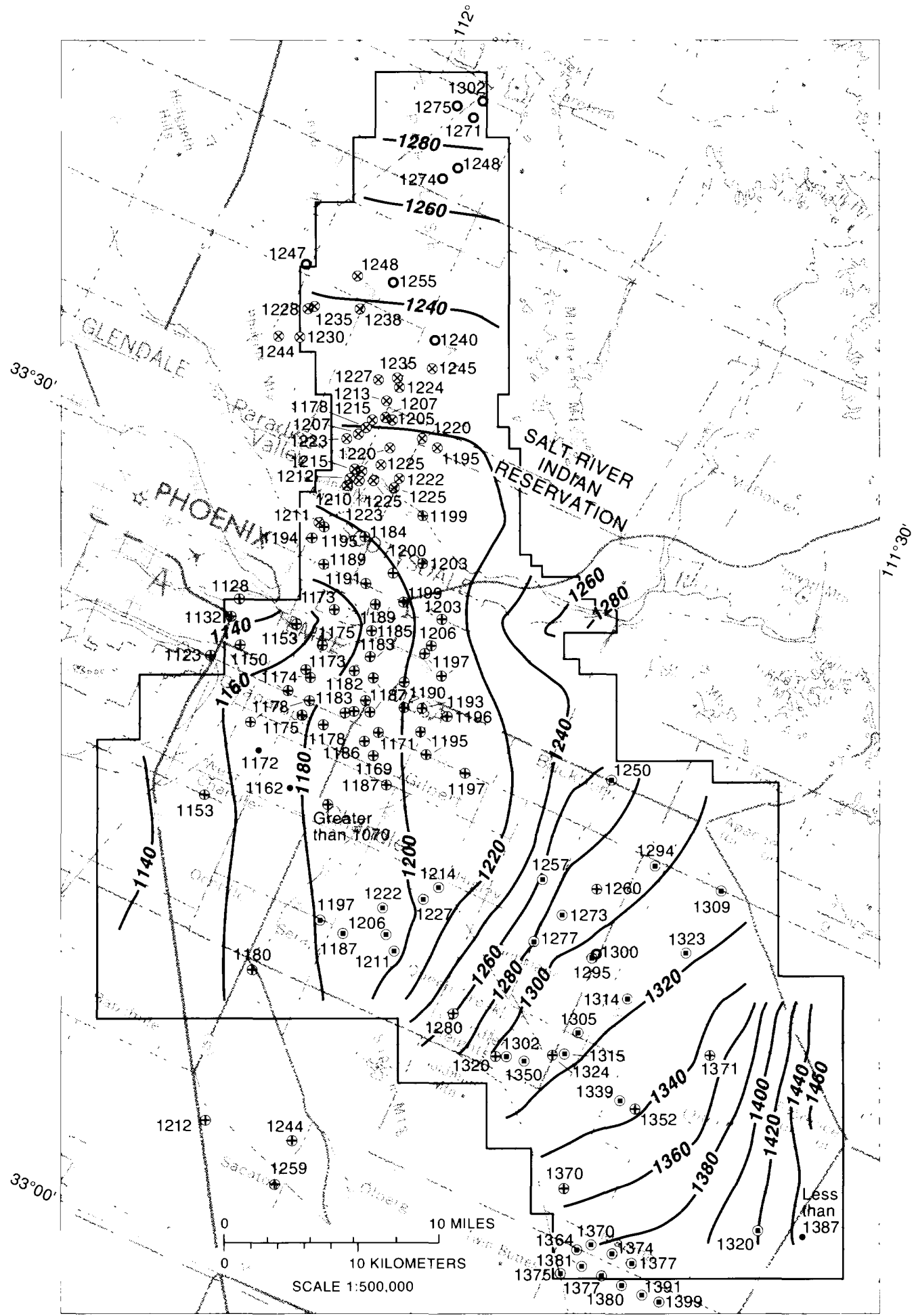

Base from U S. Geological Survey State base map, 1:500,000, 1972

EXPLANATION

WELL-Number, 1172, indicates altitude of the water level in feet above sea level. Sources of water-level data:

-1320 - SIMULATED WATER-LEVEL CONTOURShows altitude of the water level as estimated by the model, in feet above sea level. Contour interval 20 feet

1172 Davis (1897) $1314 \odot$ Babcock and Halpenny (1942)

$1191 \oplus$ Lee (1905)

1271 McDonald and others (1947)

BOUNDARY OF MODEL

$\otimes^{1225}$ Meinzer and Ellis (1915) 
Table 2.--Estimated and simulated values of ground-water flow components

[Flow is in acre-feet per year]

\begin{tabular}{|c|c|c|c|}
\hline Flow component & $\begin{array}{l}\text { Estimated } \\
\text { flow in the } \\
\text { modeled area }\end{array}$ & $\begin{array}{l}\text { Simulated } \\
\text { flow in the } \\
\text { modeled area }\end{array}$ & $\begin{array}{l}\text { Simulated flow } \\
\text { in the Salt } \\
\text { River Indian } \\
\text { Reservation }\end{array}$ \\
\hline \multicolumn{4}{|l|}{ INFLOW } \\
\hline Recharge from Salt River & 38,000 & 19,700 & 19,700 \\
\hline $\begin{array}{l}\text { Mountain-front recharge } \\
\text { and subsurface inflow }\end{array}$ & 10,000 & 10,700 & 27.000 \\
\hline Total aquifer recharge & 48,000 & 30,400 & 26,700 \\
\hline \multicolumn{4}{|l|}{ OUTFLOW } \\
\hline Discharge to Salt River & 25,000 & 9,800 & 5,000 \\
\hline Evapotranspiration & 15,000 & 13,300 & 8,100 \\
\hline \multicolumn{4}{|l|}{ Subsurface outflow } \\
\hline At Tempe Butte & 1,000 & 800 & $\ldots .$. \\
\hline At Gila River & 7,000 & 6,500 & $\ldots \ldots$ \\
\hline Total & 8.000 & 7.300 & 13.600 \\
\hline Total aquifer discharge & 48,000 & 30,400 & 26,700 \\
\hline NET FLUX FROM SALT RIVER 3 & 13,000 & 9,900 & 14,700 \\
\hline
\end{tabular}

${ }^{1}$ The modeled area includes the Salt River Indian Reservation.

${ }^{2}$ Subsurface inflow to the reservation from Cave Creek is 6,700 acre-feet and mountain-front recharge within the reservation is 300 acre-feet per year.

${ }^{3}$ Recharge from the Salt River minus discharge to the Salt River equals net flux.

The simulated predevelopment ground-water flow budget indicated that the Salt River was the dominant source of recharge to the regional aquifer, and evapotranspiration was the dominant sink. The net flux from the river was 9,900 acre-ft/yr. The simulated and estimated magnitudes of evapotranspiration were nearly identical, but the simulated discharge to the Salt River was much less than was estimated. The large difference between the simulated and estimated values of the discharge to the Salt River suggests that the estimated value was corrupted by irrigation return flow resulting from canal leakage and irrigation techniques. Most simulated regional ground-water flow components were less than initial 
estimates. The difference between estimated and simulated values ranged from about 10 percent for evapotranspiration to about 60 percent for discharge to the Salt River.

\section{Sensitivity Analysis}

The sensitivity analysis, which is the principal means of assessing the credibility of the calibrated model, was designed to illustrate the changes in head profiles and flow components that result from variations of parameter values. The analysis was done by performing a series of simulations in which all parameters were held constant except the one being analyzed, and that parameter was varied over a broad range of values that were considered reasonable. Transmissivity, mountain-front recharge, riverbed conductance, evapotranspiration-extinction depths, and evapotranspiration rates were all varied independently. Simulated heads within the Salt River Indian Reservation were evaluated in each sensitivity simulation by constructing head profiles along a stream line through the middle of the reservation extending from the base of the McDowell Mountains westward and southwestward toward the Salt River (fig. 4). This profile represented the head distribution along a stream line in the calibrated model but not necessarily along a stream line in the sensitivity runs. The sensitivity of heads along the profile may not be indicative of sensitivity everywhere in the model. The average-absolute and root-mean-square values of head residuals of each simulation were compared in order to assess the sensitivity of heads throughout the valley (table 3).

\section{Sensitivity of Heads}

Heads along the stream line were sensitive to all parameters except the two evapotranspiration parameters. Head changes were negatively correlated to changes in transmissivity along the east $7 \mathrm{mi}$ of the profile, insensitive along a 3 -mile reach above the river, and positively correlated to transmissivity changes at Tempe Butte (fig. 8). Heads generally were insensitive to riverbed-conductance values greater than the calibrated values indicating that the river was acting nearly as a constant-head boundary because of the high riverbed-conductance values. Lower conductances flattened the head gradient noticeably (fig. 9). Changes in head were positively correlated to changes in simulated boundary flux; the degree of sensitivity decreased steadily downgradient toward Tempe Butte where heads in the lower $4 \mathrm{mi}$ of the profile were insensitive to boundary-flux changes ( $f 1 g .10$ ).

Head-residual statistics followed the same general sensitivity trends as the head profile; however, decreases in riverbed conductance had little influence on the residuals (table 3 ) in comparison with the noticeable influence on the slope of the profile (fig. 9). The headresidual statistics were insensitive to variations in most parameters because the residual values were distributed throughout the entire study area; whereas, the sensitivity of the head profile resulted from its representation of a single stream line. 
Table 3.--Sensitivity of head-residual statistics to model parameters

\begin{tabular}{ccc}
\hline $\begin{array}{c}\text { Multiplier of } \\
\text { calibrated } \\
\text { value }\end{array}$ & $\begin{array}{c}\text { Percent change } \\
\text { in average- } \\
\text { absolute head }\end{array}$ & $\begin{array}{c}\text { Percent change } \\
\text { in root-mean- } \\
\text { square value }\end{array}$ \\
\hline & Transmissivity & \\
\hline 0.50 & 387 & 416 \\
.75 & 104 & 111 \\
1.00 & 0 & 0 \\
1.25 & 31 & 18 \\
1.50 & 73 & 63 \\
2.00 & 137 & 133 \\
\hline
\end{tabular}

Evapotranspiration extinction depth

\begin{tabular}{|c|c|c|}
\hline $\begin{array}{r}0.33 \\
.67 \\
1.00 \\
1.33 \\
1.67\end{array}$ & $\begin{array}{l}0 \\
0 \\
0 \\
0 \\
0\end{array}$ & $\begin{array}{l}0 \\
0 \\
0 \\
0 \\
0\end{array}$ \\
\hline \multicolumn{3}{|c|}{ Evapotranspiration rate } \\
\hline $\begin{array}{r}0.20 \\
.50 \\
1.00 \\
1.50 \\
2.00\end{array}$ & $\begin{array}{l}0 \\
0 \\
0 \\
0 \\
0\end{array}$ & $\begin{array}{l}0 \\
0 \\
0 \\
0 \\
0\end{array}$ \\
\hline \multicolumn{3}{|c|}{ Riverbed conductance } \\
\hline $\begin{array}{r}0.01 \\
.10 \\
1.00 \\
10.00 \\
100.00\end{array}$ & $\begin{array}{r}-5 \\
-1 \\
0 \\
0 \\
0\end{array}$ & $\begin{array}{r}-3 \\
0 \\
0 \\
0 \\
0\end{array}$ \\
\hline \multicolumn{3}{|c|}{ Mountain-front recharge } \\
\hline $\begin{array}{r}0.50 \\
.75 \\
.90 \\
1.00 \\
1.10 \\
1.25 \\
1.50 \\
2.00\end{array}$ & $\begin{array}{r}138 \\
46 \\
7 \\
0 \\
19 \\
72 \\
174 \\
391\end{array}$ & $\begin{array}{r}133 \\
33 \\
-1 \\
0 \\
22 \\
77 \\
185 \\
418\end{array}$ \\
\hline
\end{tabular}




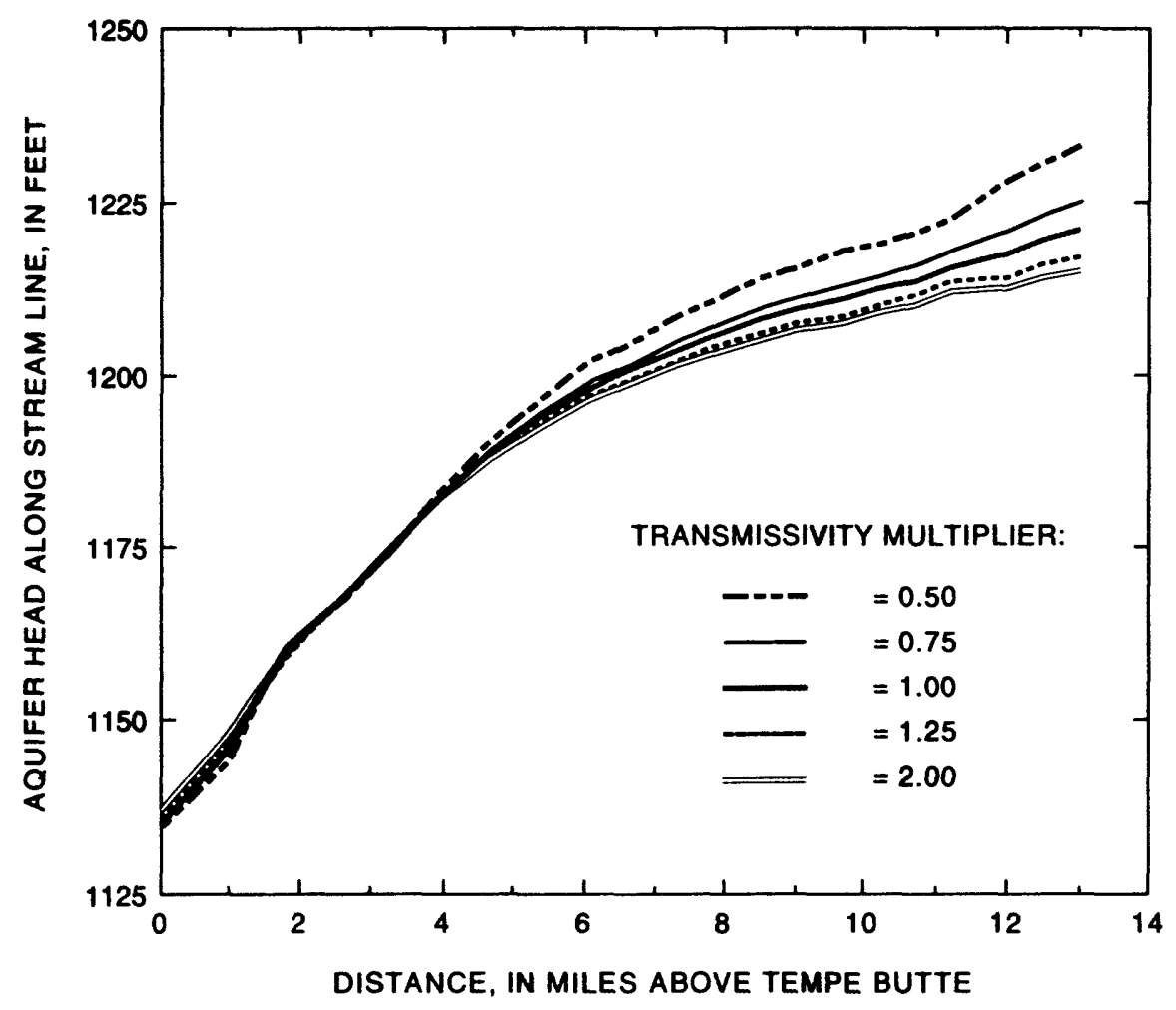

Figure 8.-Sensitivity of stream-iline profile to changes in transmissivity values.

\section{Sensitivity of Flow Components}

Flow components generally were sensitive to changes in model parameters (fig. 1i). Changes in transmissivity produced the greatest changes in the ground-water budget, whereas changes in riverbed conductance produced the least.

The net flux from the Salt River to the aquifer was insensitive to changes in riverbed conductance but highly sensitive to changes in boundary fluxes and evapotranspiration parameters (extinction depth and ground-water withdrawal rate). The net flux was negatively correlated to changes in boundary fluxes and positively correlated to changes in evapotranspiration parameters. Variations in transmissivity produced variations in the net river flux that appeared as equivalent changes in subsurface outflow. Evapotranspiration was completely unresponsive to changes in transmissivity. Changes in net river flux produced by variations in evapotranspiration parameters caused equivalent changes in the evapotranspiration component. Subsurface outflow was completely insensitive to changes in net river flux induced by variations in evapotranspiration parameters. Changes in riverbed conductance had little effect on net river flux, subsurface outflow, and evapotranspiration. Variations in mountain-front recharge (boundary flux) had a negative correlation to net river flux and had only a slight positive correlation to subsurface outflow and evapotranspiration. 


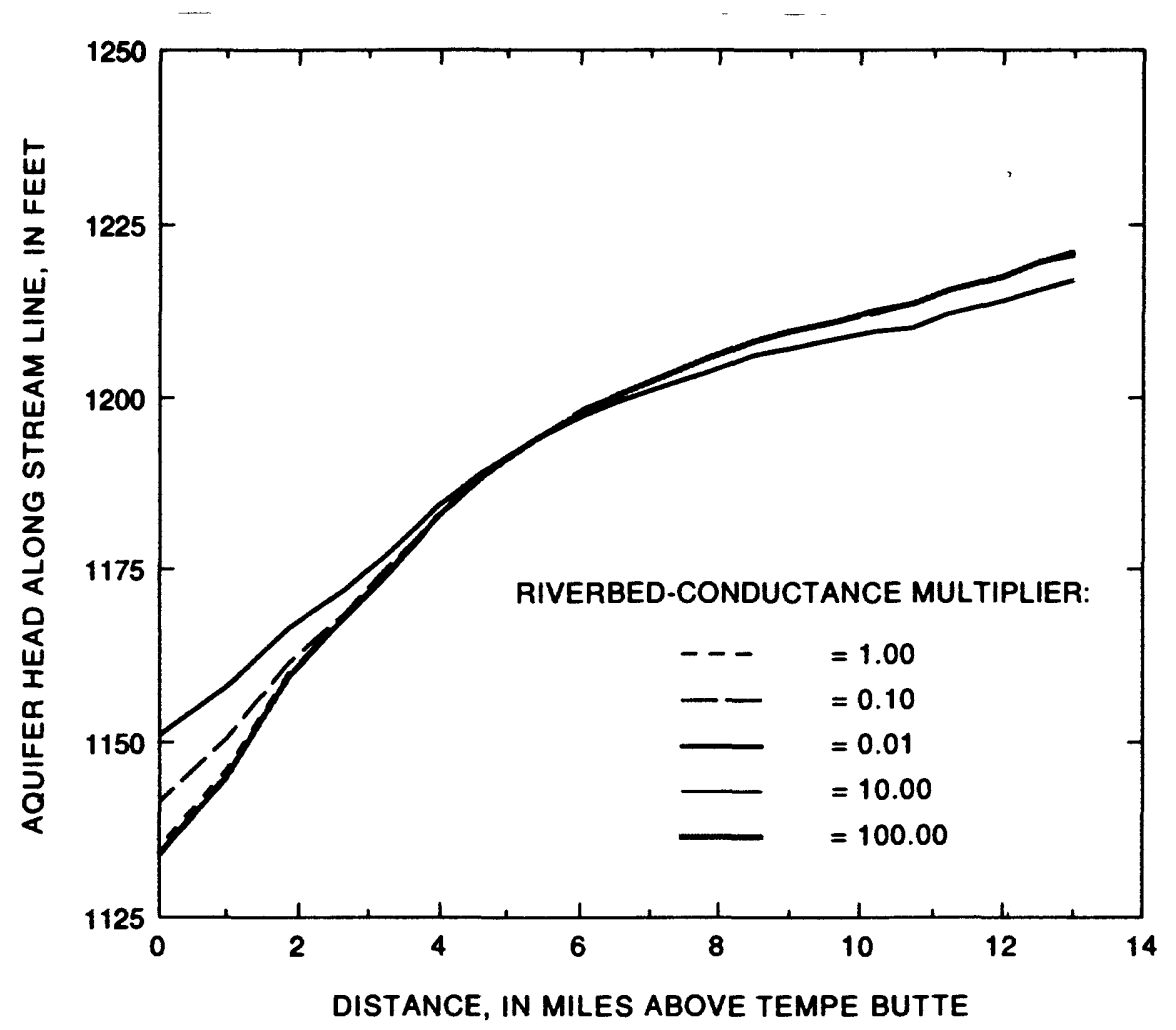

Figure 9.-Sensitivity of stream-1ine profile to changes in riverbed conductance.

Total recharge from and discharge to the river exhibited strong positive correlations to transmissivity changes. These fluxes, however, were sensitive to decreases and insensitive to increases in riverbed conductances. Increases in evapotranspiration rates and extinction depths reduced the discharge to the river and increased the recharge from the river and the net-river flux.

The flow-component sensitivity results are compatible with the head-sensitivity results and suggest that the simulated predevelopment scenario was reasonable and that the emphasis placed on the well data during the calibration process was appropriate. Net river flux and evapotranspiration along the flood plain had little influence on regional-head configurations outside the flood plain, as suggested by the insensitivity of the head profile and head residuals to most variations in evapotranspiration parameters and riverbed conductance. Head configurations were most sensitive to changes in boundary fluxes and regional variations in transmissivity.

\section{SUMMARY}

The Salt River Indian Reservation is in an area of broad desert plains separated by rugged mountains and is transected by the Salt River. Ground water occurs mainly under unconfined conditions in unconsolidated to 


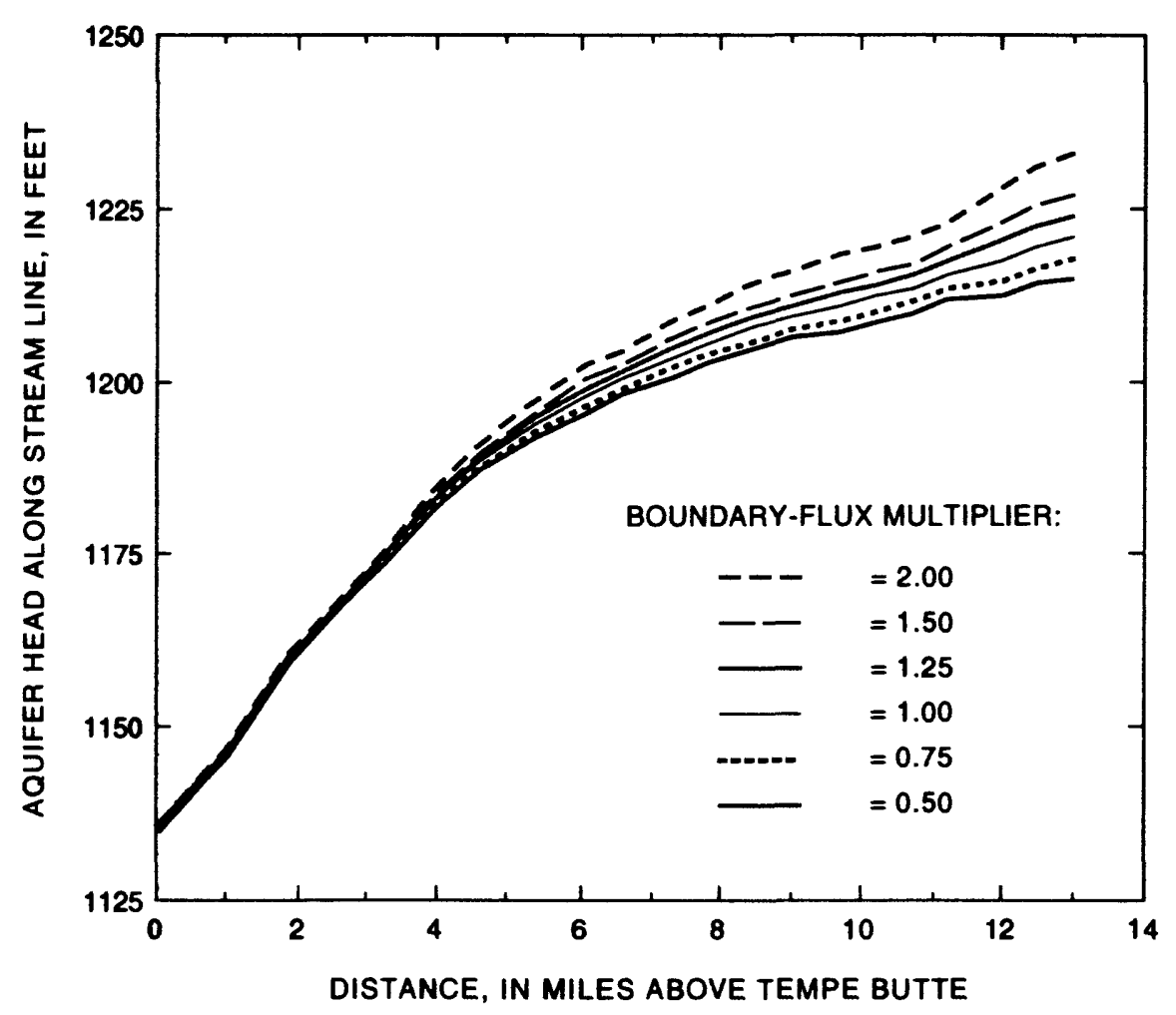

Figure 10.-Sensitivity of stream-Iine profile to changes in boundary-flux values.

variably consolidated sedimentary material that underlies the desert plains. Hydrologic conditions that existed in and near the salt River Indian Reservation prior to development by non-Indian settlers were investigated. Prior to the $1860^{\prime} \mathrm{s}$, when modern irrigation began in the Salt River Valley, flow was perennial in the Salt River. The median annual flow at Granite Reef Dam was estimated to be 950,000 acre-ft, and the average annual flow was estimated to be 1,250,000 acre-ft. Ground water was 10 to $70 \mathrm{ft}$ below the land surface in areas developed before 1900 . Infiltration from the Salt River maintained water levels at shallow depths, and ground water was discharged into the Salt River near Tempe.

Simulation of the predevelopment ground-water flow indicates that average recharge to the aquifer by infiltration from the Salt River was 19,700 acre-ft/yr. Mountain-front recharge and subsurface inflow was 10,700 acre-ft/yr. Discharge from the aquifer to the Salt River was 9,800 acre-ft/yr, subsurface outflow was $7,300 \mathrm{acre}-\mathrm{ft} / \mathrm{yr}$, and evapotranspiration from ground water was 13,300 acre-ft/yr.

\section{SELECTED REFERENCES}

Anderson, T.W., 1968, Electrical-analog analysis of ground-water depletion in central Arizona: U.S. Geological Survey Water-Supply Paper $1860,21 \mathrm{p}$. 

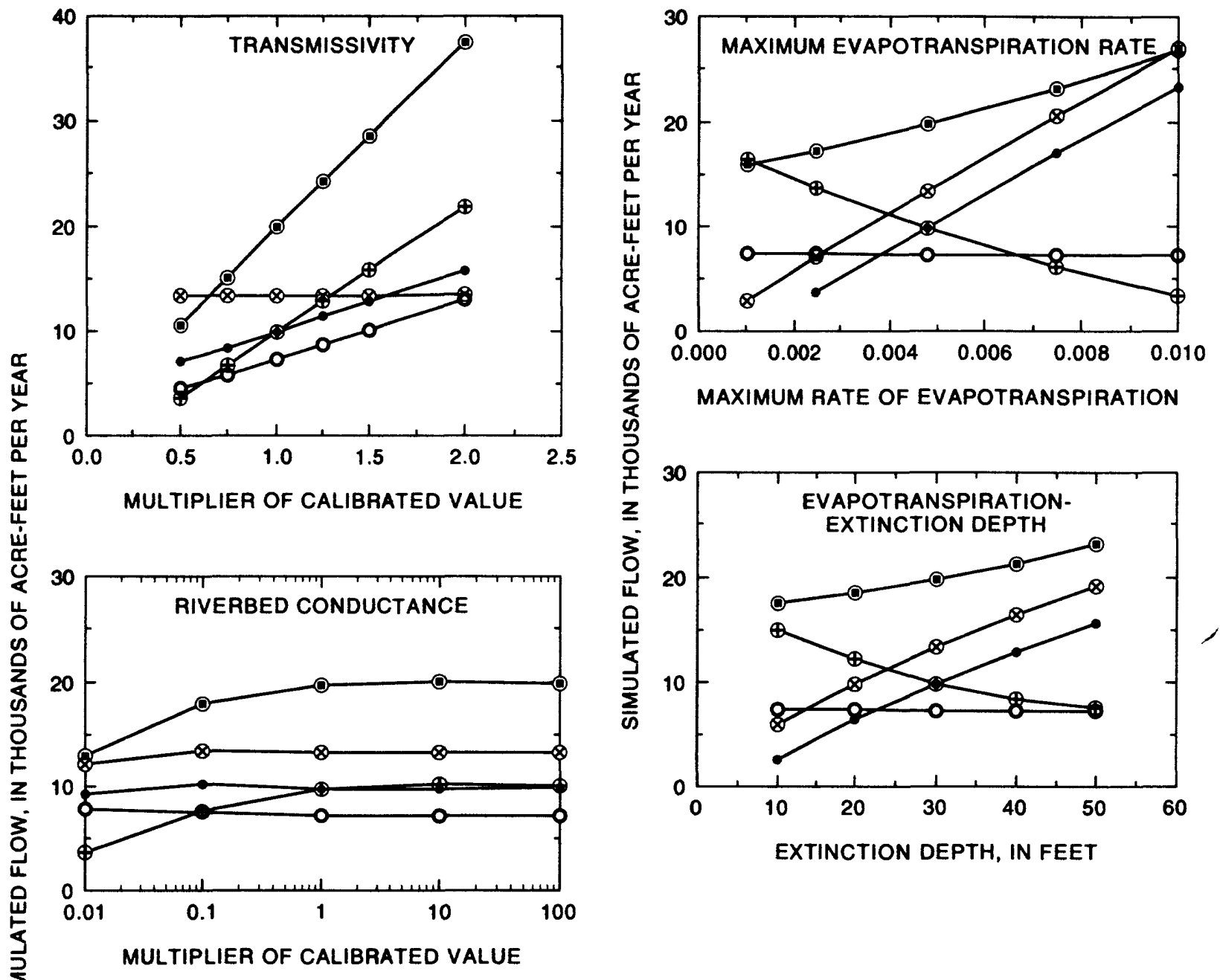

EXTINCTION DEPTH, IN FEET

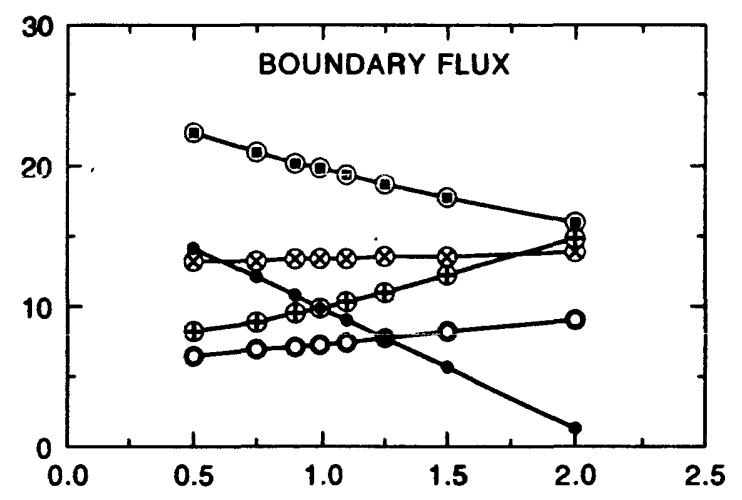

EXPLANATION

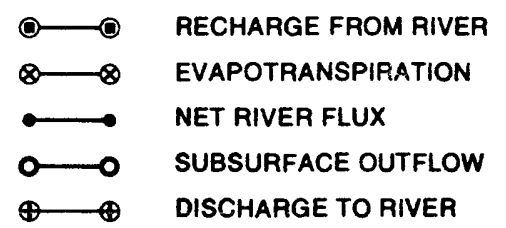

MULTIPLIER OF CALIBRATED VALUE

Figure 11.-Model sensitivity to changes in transmissivity, riverbed conductance, boundary-flux values, evapotranspiration rate, and evapotranspiration-extinction depth. 
1976, Evapotranspiration losses from flood-plain areas in central Arizona: U.S. Geological Survey Open-File Report 76-864, $91 \mathrm{p}$.

Arteaga, F.E., White, N.D., Cooley, M.E., and Sutheimer, A.F., 1968, Ground water in Paradise Valley, Maricopa County, Arizona: Arizona State Land Department Water-Resources Report 35, 76 p.

Babcock, H.M., and Halpenny, L.C., 1942, Records of wells, well logs, water analyses, and map showing locations of wells, Queen Creek area, Maricopa and Pinal Counties, Arizona: U.S. Geological Survey open-file report (unnumbered), $39 \mathrm{p}$.

Bancroft, H.H., 1889, History of Arizona and New Mexico, 1530-1888: San Francisco, California, The History Company, 829 p.

Bentall, Ray, 1963, Methods of determining permeability, transmissibility, and drawdown: U.S. Geological Survey Water-Supply Paper 1536-I, p. 243-342.

Cooley, M.E., 1977, Map of Arizona showing selected alluvial, structural, and geomorphic features: U.S. Geological Survey Open-File Report $77-343,29 \mathrm{p}$.

Culler, R.C., Hanson, R.L., Myrick, R.M., and Turner, R.M., 1982, Evapotranspiration before and after clearing phreatophytes, Gila River flood plain, Graham County, Arizona: U.S. Geological Survey Professional Paper 655-P, 67 p.

Davis, A.P., 1897, Irrigation near Phoenix, Arizona: U.S. Geological Survey Water-Supply and Irrigation Paper 2, 98 p.

Ezel1, P.H., 1963, Is there a Hohokam-Pima culture continuum?: Anerican Antiquity, v. 29, no. 1, p. 61-66.

Fenneman, N.M., 1931, Physiography of the Western United States: New York, McGraw-Hill, 534 p.

Ferris, J.G., Knowles, D.B., Brown, R.H., and Stallman, R.W, , 1962 , Theory of aquifer tests: U.S. Geological Survey Water-Supply Paper 1536-E, p. 69-174.

Freethey, G.H., and Anderson, T.W., 1986, Predevelopment hydrologic conditions in the alluvial basins of Arizona and adjacent parts of California and New Mexico: U.S. Geological Survey Hydrologic Investigations Atlas HA-664, 3 sheets.

Freethey, G.H., Poo1, D.R., Anderson, T.W., and Tucci, Patrick, 1986, Description and generalized distribution of aquifer materials in the alluvial basins of Arizona and adjacent parts of California and New Mexico: U.S. Geological Survey Hydrologic Investigations Atlas HA-663, 4 sheets.

Fritts, H.C., 1976, Tree rings and climate: London, Academic Press, 567 p. 
Fritts, H.C., Lofgren, G.R., and Gordon, G.A., 1979, Variations in climate since 1602 as reconstructed from tree rings: Seattle, University of Washington, Quaternary Research, v. 12, p. 18-46.

Gatewood, J.S., Robinson, T.W., Colby, B.R., Hem, J.D., and Halpenny, L.C., 1950, Use of water by bottom-land vegetation in lower Safford Valley, Arizona: U.S. Geological Survey Water-Supply Paper 1103, $210 \mathrm{p}$.

Haury, E.W., 1976, The Hohokam-Desert farmers and craftsmen: Tucson, University of Arizona Press, $412 \mathrm{p}$.

Hodge, F.W., 1893, Prehistoric irrigation in Arizona: Washington, D.C., The American Anthropologist, July 1893, v. 6, no. 3, p. 323-330.

Hodge, H.C., 1877, Arizona as it is; or the coming country: New York, Hurd and Houghton, $272 \mathrm{p}$.

Laney, R.L., and Hahn, M.E., 1986, Hydrogeology of the eastern part of the Salt River Valley area, Maricopa and Pinal Counties, Arizona: U.S. Geological Survey Water-Resources Investigations Report $86-4147,4$ sheets.

Laney, R.L., Ross, P.P., and Littin, G.R., 1978, Maps showing ground-water conditions in the eastern part of the Salt River Valley area, Maricopa and Pinal Counties, Arizona-1976: U.S. Geological Survey Water-Resources Investigations 78-61, 2 sheets.

Langbein, W.B., and Iseri, K.T., 1960, General introduction and hydrologic definitions: U.S. Geological Survey Water-Supply Paper 1541-A, $29 \mathrm{p}$.

Lee, W.T., 1904, The underground waters of Gila Valley, Arizona: U.S. Geological Survey Water-Supply Paper 104, 71 p.

1905, Underground waters of Salt River Valley, Arizona: U.S. Geological Survey Water-Supply Paper 136, 196 p.

Lohman, S.W., and others, 1972, Definitions of selected ground-water terms-Revisions and conceptual refinements: U.S. Geological Survey Water-Supply Paper 1988, $21 \mathrm{p}$.

Masse, W.B., 1981, Prehistoric irrigation systems in the Salt River Valley: Science, v. 214, p. 408-414.

McDonald, M.G., and Harbaugh, A.W., 1988, A modular three-dimensional finite-difference ground-water flow model: U.S. Geological Survey Techniques of Water-Resources Investigations, Book 6 , Chapter A1, $586 \mathrm{p}$.

McDonald, H.R., Wolcott, H.N., and Hem, J.D., 1947, Geology and ground-water resources of the Salt River Valley area, Maricopa and Pinal Counties, Arizona: U.S. Geological Survey open-file report, $45 \mathrm{p}$. 
Meinzer, O.E., and Ellis, A.J., 1915, Ground water for irrigation in the Sacramento Valley, California, in Contributions to the hydrology of the United States: U.S. Geological Survey Water-Supply Paper $375-$ B, P. $51-75$.

Murphy, D.W., 1920, Drainage report-Salt River Valley Water Users' Association, 1920: Phoenix, Salt River Project Archives, 18 p.

Owen-Joyce, S.J., and Be11, C.K., 1983, Appraisal of water resources in the upper Verde River area, Yavapai and Coconino Counties, Arizona: Arizona Department of Water Resources Bulletin 2, 219 p.

Reeter, R.W., and Remick, W.H., 1986, Maps showing groundwater conditions in the West Salt River, East Salt River, Lake Pleasant, Carefree and Fountain Hills sub-basins of the Phoenix Active Management Area, Maricopa, Pinal and Yavapai Counties, Arizona-1983: Arizona Department of Water Resources Hydrologic Map Series Report 12, 3 sheets.

Ross, P.P., 1980, Simulated effects of a proposed well field on the groundwater system in the Salt River Indian Reservation, Maricopa County, Arizona: U.S. Geological Survey Open-File Report 80-503-W, 22 p.

Salt River Project, 1970, The Taming of the Salt: Phoenix, Arizona, Salt River Project, $143 \mathrm{p}$.

1980, A valley reborn-The story of the Salt River Project: Phoenix, Arizona, Salt River Project, 24 p.

Sellers, W. D., 1965, Physical climatology: Chicago and London, The University of Chicago Press, $272 \mathrm{p}$.

Sellers, W.D., and Hill, R.H., eds., 1974, Arizona climate 1931-1972: Tucson, University of Arizona Press, $616 \mathrm{p}$.

Sellers, W.D., Hill, R.H., and Sanderson-Rae, Margaret, eds., 1985, Arizona climate-The first hundred years: Tucson, University of Arizona Press, $143 \mathrm{p}$.

Skibitzke, H.E., Yost, C.B., Jr., Pulido, A.D., and others, 1950, Records of wells and springs in the Queen Creek area, Maricopa and Pinal Counties, Arizona: U.S. Geological Survey open-file report (unnumbered), $73 \mathrm{p}$.

Skinner, W.W., 1903, The underground waters of Arizona-Their character and uses: Tucson, University of Arizona Agricultural Experiment Station Bulletin 46, p. 273-287.

Smith, L.P., 1981, Long-term streamflow histories of the Salt and Verde Rivers, Arizona-as reconstructed from tree rings: Tucson, University of Arizona, Laboratory of Tree-Ring Research, Report for U.S. Army Corps of Engineers Contract DACW-09-80-C-0071, $129 \mathrm{p}$. 
Smith, L.P., and Stockton, C.W., 1981, Reconstructed streamflow for the Salt and Verde Rivers from tree-ring data: Water Resources Bulletin, v. 17, no. 6, p. 939-947.

Stockton, C.W., 1971, The feasibility of augmenting hydrologic records using tree-ring data: Tucson, University of Arizona, unpublished Ph.D. dissertation, $172 \mathrm{p}$.

Stockton, C.W., 1975, Long-term streamflow records reconstructed from tree rings: Tucson, University of Arizona, Laboratory of Tree-Ring Research Paper 5, 111 p.

Thomsen, B.W., and Baldys, S., III, 1985, Ground-water conditions in and near the Gila River Indian Reservation, south-central Arizona: U.S. Geological Survey Water-Resources Investigations Report $85-4073,2$ sheets.

Thomsen, B.W., and Eychaner, J.H., 1991, Predevelopment hydrology of the Gila River Indian Reservation, south-central Arizona: U.S. Geological Survey Water-Resources Investigations Report 89-4174, $44 \mathrm{p}$.

Thomsen, B.W., and Miller, B.H., 1991, Ground-water conditions in and near the Salt River Indian Reservation, south-central Arizona: U.S. Geological Survey Water-Resources Investigations Report 89-4176, 2 sheets.

U.S. Department of Commerce, 1968, Climatic atlas of the United States: Environmental Science Services Administration, Department of Commerce, Washington, D.C., 80 p.

U.S. Geological Survey, 1954, Compilation of records of surface waters of the United States through September 1950, Part 9, Colorado River basin: U.S. Geological Survey Water-Supply Paper 1313, 149 p.

1986, Annual summary of ground-water conditions in Arizona, spring 1984 to spring 1985: U.S. Geological Survey Open-File Report 86-442-W, 2 sheets.

Van Hylckama, T.E.A., 1974, Water use by saltcedar as measured by the water-budget method: U.S. Geological Survey Professional Paper 491-E, 30 p.

Walton, W.C., and Pickett, T.A., 1963, Hydrogeologic electric-analog computers: Journal of the Hydraulics Division, American Society of Civil Engineers, v. 89, no. HY6, p. 67-91. 